\title{
Breaking the mold: transcription factors in the anucleate platelet and platelet-derived microparticles
}

\section{Katie L. Lannan' ${ }^{1}$ Julie Sahler ${ }^{1,2}$, Nina Kim ${ }^{1}$, Sherry L. Spinelli ${ }^{3}$, Sanjay B. Maggirwar ${ }^{1}$, Olivier Garraud ${ }^{4}$, Fabrice Cognasse ${ }^{4,5}$, Neil Blumberg ${ }^{3}$ and Richard P. Phipps ${ }^{1,3,6 *}$}

${ }^{1}$ Department of Microbiology and Immunology, University of Rochester School of Medicine and Dentistry, Rochester, NY, USA

${ }^{2}$ Department of Biological and Environmental Engineering, Cornell University, Ithaca, NY, USA

${ }^{3}$ Department of Pathology and Laboratory Medicine, University of Rochester School of Medicine and Dentistry, Rochester, NY, USA

${ }^{4}$ Faculté de Médecine, Université de Lyon, Saint-Etienne, France

${ }^{5}$ Etablissement Français du Sang Auvergne-Loire, Saint-Etienne, France

${ }^{6}$ Department of Environmental Medicine, University of Rochester School of Medicine and Dentistry, Rochester, NY, USA

\section{Edited by:}

Masaaki Murakami, Hokkaido

University, Japan

Reviewed by:

Daisuke Kamimura, Hokkaido

University, Japan

Hideki Ogura, Yale University, USA

\section{*Correspondence:}

Richard P. Phipps, Department of

Environmental Medicine, University

of Rochester, 601 Elmwood Avenue,

Rochester, NY 14642, USA

e-mail: richard_phipps@urmc.

rochester.edu

\begin{abstract}
Platelets are small anucleate blood cells derived from megakaryocytes. In addition to their pivotal roles in hemostasis, platelets are the smallest, yet most abundant, immune cells and regulate inflammation, immunity, and disease progression. Although platelets lack DNA, and thus no functional transcriptional activities, they are nonetheless rich sources of RNAs, possess an intact spliceosome, and are thus capable of synthesizing proteins. Previously, it was thought that platelet RNAs and translational machinery were remnants from the megakaryocyte. We now know that the initial description of platelets as "cellular fragments" is an antiquated notion, as mounting evidence suggests otherwise. Therefore, it is reasonable to hypothesize that platelet transcription factors are not vestigial remnants from megakaryocytes, but have important, if only partly understood functions. Proteins play multiple cellular roles to minimize energy expenditure for maximum cellular function; thus, the same can be expected for transcription factors. In fact, numerous transcription factors have non-genomic roles, both in platelets and in nucleated cells. Our lab and others have discovered the presence and non-genomic roles of transcription factors in platelets, such as the nuclear factor kappa $\beta$ (NFкB) family of proteins and peroxisome proliferator-activated receptor gamma (PPAR $\gamma$ ). In addition to numerous roles in regulating platelet activation, functional transcription factors can be transferred to vascular and immune cells through platelet microparticles. This method of transcellular delivery of key immune molecules may be a vital mechanism by which platelet transcription factors regulate inflammation and immunity. At the very least, platelets are an ideal model cell to dissect out the nongenomic roles of transcription factors in nucleated cells. There is abundant evidence to suggest that transcription factors in platelets play key roles in regulating inflammatory and hemostatic functions.
\end{abstract}

Keywords: platelets, microparticles, transcription factors, NF-kappa B, PPAR gamma, non-genomic, PPAR alpha, steroid receptors

\section{INTRODUCTION}

Platelets are central players in hemostasis and inflammation, contributing to numerous pathophysiologic conditions (1). They are unique from the majority of mammalian cells apart from red blood cells in that they lack a nucleus, and thus have previously been discounted as "cellular fragments." This antiquated notion has been refuted many times over as platelets are now emerging as cellular mediators of cancer cell metastasis, atherosclerosis, type II diabetes, and even mediate adaptive immune responses $(2,3)$. Platelets are metabolically active cells that contain numerous functional organelles, such as endoplasmic reticulum, Golgi apparatus, mitochondria, and granules that can be released upon activation. Although their lack of a nucleus prevents de novo transcription, they can be activated very rapidly to release copious amounts of biological mediators within seconds to minutes of stimulation.
The idea that platelets contain transcription factors is a relatively new concept and has led to the discovery of a large number of transcription factors in platelets (Table 1). This review will discuss the newly described roles of transcription factors in platelets, in addition to proposing uninvestigated potential roles of transcription factors in platelets, as extrapolated from findings in nucleated cells (Table 2).

\section{NUCLEAR FACTOR KAPPA $\beta$}

In the Immunology field, nuclear factor kappa $\beta$ (NFкB) is the most widely recognized transcription factor for its quintessential roles in regulating inflammation and immune responses. Almost any immunologist could rattle off key parts of its signaling pathways in response to toll-like receptor (TLR) signaling, influenza infection, or in cytokine production. Although we are quick to 
identify its essential roles in regulating transcription of inflammatory genes, the non-genomic roles of $\mathrm{NF \kappa B}$ are often overlooked. In all fairness, the concept that $\mathrm{NF} \kappa \mathrm{B}$ has non-genomic roles in nucleated and non-nucleated cells is a relatively new area of study that is still in its early stages (4). NFאB signaling molecules regulate several different stages of the inflammatory response, without ever entering the nucleus. For example, the NFкB regulatory protein, IkappaB kinase $\beta$ (IKK $\beta$ ), can alter the function of numerous proteins via phosphorylation in addition to regulating signaling through direct interactions with cellular effector molecules (5).

Table 1 | Identified transcription factors in platelets.

\begin{tabular}{|c|c|c|}
\hline $\begin{array}{l}\text { Transcription } \\
\text { factor }\end{array}$ & $\begin{array}{l}\text { Activation of } \\
\text { transcription factor }\end{array}$ & Agonist-induced activation \\
\hline p65 & Phosphorylation & $\begin{array}{l}\uparrow \text { Aggregation, spreading, clot } \\
\text { retraction, GPIB } \alpha \text { shedding }\end{array}$ \\
\hline \multirow[t]{2}{*}{ PPAR $\gamma$} & $\begin{array}{l}\text { Ligand binding (15d-PGJ } 2 \text {, } \\
\text { TZDs) }\end{array}$ & $\begin{array}{l}\downarrow \text { Aggregation, CD40L, } \mathrm{TXB}_{2} \text {, } \\
\text { P-selectin }\end{array}$ \\
\hline & Phosphorylation & $\begin{array}{l}\uparrow \text { Collagen-induced activation } \\
\text { and granule secretion }\end{array}$ \\
\hline $\mathrm{PPAR} \beta / \delta$ & $\begin{array}{l}\text { Ligand binding } \\
\left(\mathrm{GW} 501516, \mathrm{PGI}_{2}\right)\end{array}$ & $\downarrow$ Aggregation \\
\hline \multirow[t]{2}{*}{ PPAR $\alpha$} & Ligand binding (fenofibrate) & $\downarrow$ Aggregation \\
\hline & Phosphorylation & $\uparrow$ Activation \\
\hline $\operatorname{LXR} \beta$ & Ligand binding & $\begin{array}{l}\downarrow \text { Collagen-induced } \\
\text { aggregation }\end{array}$ \\
\hline $\mathrm{RXR} \alpha$ & Ligand binding (9cRA) & $\downarrow$ Activation \\
\hline \multirow[t]{2}{*}{ GR } & $\begin{array}{l}\text { Ligand binding } \\
\text { (prednisolone) }\end{array}$ & $\downarrow$ Activation \\
\hline & $\begin{array}{l}\text { Ligand binding } \\
\text { (dexamethasone) }\end{array}$ & Unknown \\
\hline AHR & Ligand binding & $\uparrow$ Activation \\
\hline STAT3 & Phosphorylation & $\begin{array}{l}\uparrow \text { Aggregation, P-selectin, } \\
\text { thrombosis }\end{array}$ \\
\hline
\end{tabular}

\section{IKAPPAB KINASE IN PLATELETS}

Specifically in platelets, the presence and non-genomic functions of NFKB family members have been demonstrated by several groups, including our own (6-9). Our group discovered the presence of the majority of NFKB family members in human platelets, including the canonical p50/p65 subunits, RelB and c-Rel. Additionally, we identified the presence of I $\mathrm{B}$ proteins and IKK members, which regulate NFאB activation (6). Importantly, these findings suggest that platelets contain an intact, functional, and complete NFKB pathway. The use of the irreversible inhibitor of IKK $\beta$ phosphorylation, BAY 11-7082 (BAY), has elucidated complex roles for NFKB in platelet signaling. In human platelets, BAY inhibits platelet spreading and clot retraction, and may alter aggregation at higher doses $(6,10,11)$. Malaver et al. (7) and Chen et al. (12) show that high concentrations of BAY $(10-25 \mu \mathrm{M})$ inhibit platelet aggregation, while our group saw no effect when platelets were treated with $0.5-5 \mu \mathrm{M}$ BAY (6). As the $\mathrm{IC}_{50}$ of BAY for inhibition of IKK-mediated phosphorylation of I $\kappa \mathrm{B} \alpha$ is $10 \mu \mathrm{M},<5 \mu \mathrm{M}$ BAY may be too low to inhibit IKK sufficiently to affect aggregation (13). Another possibility is that IKK inhibition exerts a threshold response in affecting platelet aggregation, rather than a doseresponse. Using genetic approaches, Karim et al. demonstrated that IKK $\beta$ knockout mice have variable, but generally attenuated, aggregation responses to platelet agonists, which may explain some of the variations observed in human studies as well (14).

Interestingly, the data reported by Chen et al. and Malavar et al. suggest that the second wave of aggregation was most affected by IKK $\beta$ inhibition, thus affecting the maximum aggregation and potentiation of the response in human platelets $(7,12)$. In accordance with this finding, dense granule release was consistently and potently reduced by IKK $\beta$ inhibition in these and other studies. This finding is likely explained by the ability of IKK $\beta$ to phosphorylate synaptosomal-associated protein-23 (SNAP-23), an integral regulator of granule secretion (14). SNAP-23 is a member of the target sensitive factor attachment protein receptors (SNARE) complex, which interacts with the vesicle-associated membrane protein (VAMP) to facilitate granule release. IKK $\beta$ appears to be central in enhancing soluble $N$-ethylmaleimide-SNARE complex formation

Table 2 | Identified and possible interactions of transcription factors in platelets with other proteins.

\begin{tabular}{|c|c|c|c|c|}
\hline \multirow[t]{2}{*}{ Transcription factor } & \multicolumn{2}{|c|}{ Known protein interaction } & \multicolumn{2}{|c|}{ Possible protein interactions } \\
\hline & Binding partners & Outcome & Binding partners & Outcome \\
\hline \multirow[t]{3}{*}{ PPAR $\gamma$} & Syk, LAT & Platelet activation & $N F_{\kappa} B(p 65)$ & $\begin{array}{l}\text { Inhibit NFKB activity } \rightarrow \text { anti-platelet } \\
\text { effect }\end{array}$ \\
\hline & $p-E R K, p-p 38$ & Granule secretion & MEK/ERK & Increased activation \\
\hline & $\mathrm{PKC} \alpha$ & Reduce PKC $\alpha$ activation & & \\
\hline $\operatorname{PPAR} \beta / \delta$ & $\mathrm{PKC} \alpha$ & Dampen platelet adhesion & - & - \\
\hline $\operatorname{PPAR} \alpha$ & NFkB & Inhibit NFאB activity $\rightarrow$ anti-platelet effect & $\mathrm{PKC} \alpha$ & Increased activation \\
\hline $\operatorname{LXR} \beta$ & Syk, LAT & Dampen platelet activation & PPAR $\gamma$ & Unknown \\
\hline $\mathrm{RXR} \alpha$ & PPAR $\gamma$ & Unknown & $\mathrm{G}_{\mathrm{q}}$ & Decreased activation \\
\hline \multirow[t]{2}{*}{ GR } & HSP90 & Unknown & - & - \\
\hline & Mineralocorticoid Receptor & Unknown & - & - \\
\hline $\mathrm{AHR}$ & - & - & $N F_{\kappa} B(p 65)$ & Unknown \\
\hline
\end{tabular}


though the phosphorylation of SNAP-23. Consequently, platelets from IKK $\beta$ knockout mice have a reduced ability to release alpha, dense, and lysosomal granules upon thrombin stimulation by approximately $30 \%$. Likewise, treatment of mouse or human platelets with an inhibitor of IKK $\beta$ similarly reduced granule secretion upon stimulation. These data suggest that the NFKB signaling molecule, IKK $\beta$, plays an important regulatory role in platelet activation by transducing critical stimulatory signals.

In general, genetic ablation or pharmacological inhibition of IKK $\beta$ in mice results in a hyporesponsive phenotype to agonistinduced platelet activation. Inhibition of IKK $\beta$ in mice prolonged thrombus formation and increased bleeding times (14). Additionally, a second IKK $\beta$ inhibitor, IKK inhibitor VII, recapitulated several of the aforementioned findings in both human and mouse platelets, including preventing P-selectin expression and dampening aggregation (15). Of note, Gambaryan et al. found that IKK inhibitor VII potentiated collagen and thrombin-induced aggregation, rather than having an inhibitory effect (8). They proposed a model in which thrombin and collagen induce a negative feedback loop in platelets that inhibits platelet function through NFKB. Although the work delves into the complex agonist-induced signaling pathways of NFKB in platelets, their data showing potentiation of platelet activation by IKK inhibitor VII is less clear-cut. Treatment of human platelets with IKK inhibitor VII enhanced very low dose $(0.001 \mathrm{U} / \mathrm{mL})$ thrombin-induced PAC1 binding by approximately $15 \%$. Additionally, IKK inhibitor VII treatment only mildly potentiated collagen $(10 \mu \mathrm{g} / \mathrm{mL})$ and thrombin $(0.01 \mathrm{U} / \mathrm{mL})$-induced platelet aggregation, with a slight left shift in the aggregation traces compared to control. However, the maximum amplitude of aggregation was indistinguishable between IKK inhibitor VII treatment and control. Although the data demonstrating NFKB signaling post-activation are intriguing, the current consensus is that NFKB primarily plays an important role in positively regulating platelet activation.

As much of the investigations into the non-genomic roles of the transcription factor, $\mathrm{NF \kappa} B$, has involved manipulation of its upstream regulatory kinase, IKK, careful consideration must be taken into account when interpreting the findings of these studies. IKK acts as a kinase that plays a crucial role in regulating NFKB activation, but can also phosphorylate other proteins that may play regulatory roles in platelet activation (5). Thus, inhibition of IKK in platelets may dampen platelet function in a non-canonical fashion, independent of NFKB. On the other hand, many studies have observed changes in p65 phosphorylation in platelets, although the effects of direct inhibition or deletion of p65 has not been investigated to date. It is likely that IKK activation in platelets results in NFKB-dependent and -independent regulation of platelet function. This is supported by the data showing that IKK phosphorylates SNAP-23 (14), leading to granule secretion, but can also activate $\mathrm{p} 65$, which can regulate protein kinase $\mathrm{A}$ (PKA) (8).

\section{NFKB IN PLATELETS DURING INFLAMMATION}

Nuclear factor kappa $\beta$ in nucleated cells is known to play a crucial role in inflammatory diseases, although its functions in platelets during inflammation are still under active investigation.
In one study, IKK $\beta$ deficiency increased neointimal formation in low-density lipoprotein receptor (LDLR) knockout mice and exhibited increased leukocyte adherence to the vessel walls after injury (16). Upon further investigation, IKK $\beta$-deficient platelets were unable to shed GPIb $\alpha$ in response to thrombin stimulation. Interestingly, GPIb $\alpha$ shedding in response to ADP or collagen was not affected, suggesting that IKK $\beta$ is uniquely involved in thrombin-induced GPIb $\alpha$ shedding. These data are intriguing in light of the fact that many studies evaluating the role of IKK $\beta$ in platelets focused on thrombin-induced activation and signaling. However, collagen and ADP-induced aggregation and granule secretion were also dampened by IKK $\beta$ deficiency or pharmacological inhibition. Furthermore, no differences in GPVI, GPIX, or $\alpha \operatorname{IIb} \beta 3$ shedding were found by loss of IKK $\beta$ in mouse platelets. These data suggest that although IKK $\beta$ plays an important role in the activation of platelets, it may also induce an inhibitory feedback loop, as proposed by Gambaryan et al., perhaps through shedding of GPIb $\alpha$ (8). Sustained levels of GPIb $\alpha$ on the platelet surface can enhance platelet-leukocyte interactions, and thus, may exacerbate certain conditions.

Platelets are also known to response to various immunologic stimuli, such as TLR ligands (17). In nucleated cells, bacterial lipopolysaccharide (LPS) signaling through TLR4 is largely through $\mathrm{NF} \kappa \mathrm{B}$, leading to the production of proinflammatory cytokines and chemokines. We have recently shown that platelets can discriminate between different isoforms of LPS (18). This suggests that platelets are capable of specifically sensing and responding to various bacterial products. Thus, it is possible that LPS signaling in platelets involves differential NFkB activation, although this has not been investigated in platelets to date.

\section{SIGNALING MECHANISM OF NFKB IN PLATELETS}

Thrombin activates the NFKB signaling cascade in platelets, although the complete pathway has not yet been elucidated. Several lines of evidence suggest that p38 mitogen-activated protein kinase (MAPK) signaling is upstream of NFKB in platelets, while the extracellular signal-regulated kinase (ERK) pathway is downstream of NFKB activation $(19,20)$. In human platelets, inhibition of MAPK prevented collagen-induced IKK $\beta$ and p65 phosphorylation, while treatment with an ERK inhibitor had no effect. Furthermore, collagen-induced ERK phosphorylation was prevented by pretreatment with an MAPK inhibitor or the NFKB inhibitor BAY, suggesting that NFKB signaling regulates ERK activation. ERK activates phospholipase $\mathrm{A}_{2}\left(\mathrm{PLA}_{2}\right)$, which releases arachidonic acid, leading to platelet aggregation and mediator release. This explains why arachidonic acid-induced platelet aggregation is unaffected by NFKB inhibitors, while aggregation in response to other agonists is dampened. Interestingly, one study suggests that activation of NFKB by CD40L signaling may be independent of p38 MAPK, but may instead involve TRAF2 activation of IKK $\beta$ (15). Additionally, protease-activated receptor 4 (PAR4) stimulation led to ceramide production by sphingomyelin phosphodiesterase (Smase), which in turn activated MAPK, while PAR1 signaling was independent of ceramide (12). This is consistent with the finding that exogenous treatment of platelets with ceramide leads to in vitro activation and enhances thrombosis in vivo. PAR1 
and PAR4 are the thrombin receptors on human platelets, with PAR1 having a lower threshold for activation by thrombin than PAR4 (21). PAR1 activation typically induces a rapid, but transient spike in calcium, while PAR4 activation involves a more sustained response, suggesting overlapping, but distinct roles for these receptors (22). These data reveal a novel and distinct signaling pathway for PAR1 and PAR4 receptors, although both converge on NFKB signaling.

Taken together, these data present compelling evidence that NFKB plays an important, albeit complex, role in platelet activation (Figure 1). The data support a model whereby platelet activation through various receptors leads to phosphorylation and activation of IKK $\beta$, release of p65, and subsequent platelet aggregation and granule release. This model, however, is not mutually exclusive of the idea that NFאB may induce a negative inhibitory feedback loop in platelets (8). After dissociation of p65 from its inhibitory complex, PKA is free to induce vasodilator-stimulated phosphoprotein (VASP) phosphorylation, which mediates platelet inhibitory signaling. This may represent a mechanism to fine tune platelet activation after thrombin stimulation. In fact, $\mathrm{PIP}_{3}$ can induce VASP phosphorylation, leading to inhibitory signaling, in addition to activating IKK through protein kinase B, also known as Akt. Thrombin signaling also appears to be unique in that it stimulates GPIb shedding through NFאB and ADAM17, unlike ADP or collagen-induced activation (16). ADAM17 is a sheddase that is critical for platelet surface receptor shedding and can be activated by p38 MAPK (23). Unlike pharmacological inhibition of NFKB in human platelets, IKK-deficient mouse platelets are unable to phosphorylate p38 MAPK after thrombin stimulation (16). This raises the question as to whether defective GPIb shedding in IKK $\beta$ deficient mouse platelets is an artifact of interspecies variability, differences in inhibition versus complete lack of IKK $\beta$, or merely a technical timing issue. Regardless, it will be necessary to investigate the role of ADAM17 and GPIb shedding in human platelet NFKB signaling.

\section{NON-GENOMIC FUNCTIONS OF NFKB: LESSONS FROM NUCLEATED CELLS}

Nuclear factor kappa $\beta$ is a versatile family of proteins capable of performing multiple functions in nucleated cells apart

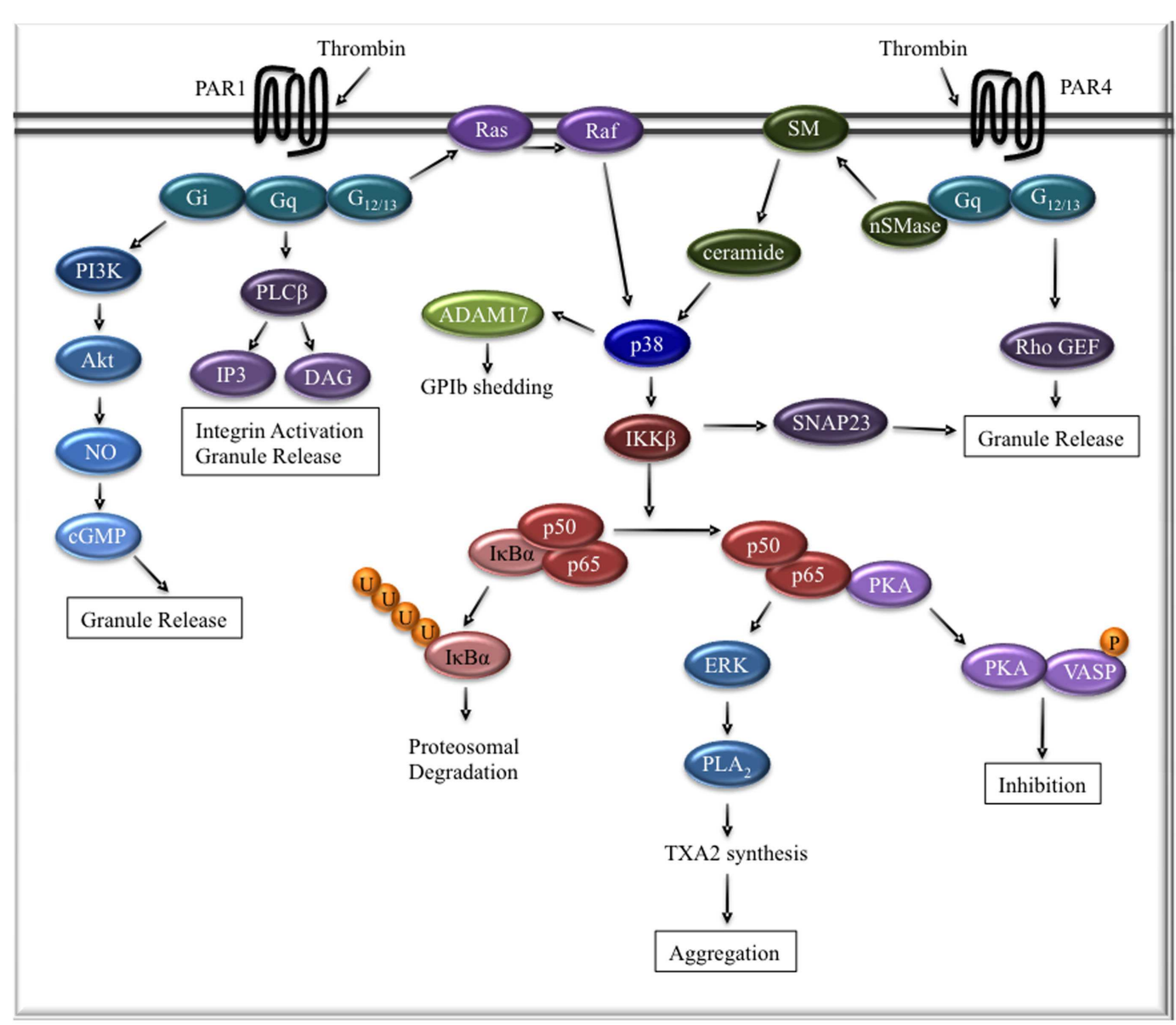

FIGURE 1 |The role of $\mathrm{NFKB}$ in platelet thrombin signaling

Thrombin signaling through PAR1 in human platelets is mostly independent of $\mathrm{NF}_{K} \mathrm{~B}$. PAR4 signaling in human platelets involves activation of p38 MAPK through ceramide signaling. Activated p38 MAPK phosphorylates IKK $\beta$, leading to the subsequent ubiquitination and proteosomal degradation of the inhibitory $I_{\kappa} B \alpha$ protein. Active p50/p65 dimers activate the ERK signaling cascade, which is involved in thromboxane $\mathrm{TXA}_{2}$ synthesis and aggregation. The p65 subunit can also bind PKA, inducing a negative feedback loop through VASP phosphorylation. 
from acting as a transcription factor (5). Evaluating these identified non-genomic roles in nucleated cells is likely to translate to important regulatory functions in platelets. Although roles for IKK $\beta$ in platelets have already been identified, studies from nucleated cells suggest that there may be more. A strong contender is the role of IKK $\beta$ in platelet spreading, as inhibition of IKK $\beta$ in human platelets leads to a spreading defect. In epithelial cells and B-lymphocytes, IKK $\beta$-mediated phosphorylation of Dok1 inhibits ERK activation, leading to increased cell motility (24). Platelets are known to transiently activate ERK, which is important for alpha granule release. However, outside-in integrin signaling through the fibrinogen receptor, as is likely to occur during platelet spreading, inhibits ERK signaling (25). Thus, inhibiting IKK $\beta$ may impair platelet spreading through a similar Dok1-mediated mechanism. Proteomic data have identified the presence of Dok1 in human platelets, although its function has yet to be studied in this context (26).

The NF $\mathrm{B}$ protein $\mathrm{p} 65$ and $\mathrm{I} \kappa \mathrm{B} \alpha$, are found in the mitochondria and appear to be differentially regulated compared to their cytoplasmic counterparts (27). Interestingly, canonical NFкB stimulatory signals had no effect on the expression or phosphorylation of mitochondria-localized p65 (28). Conversely, stimulation of liver or Jurkat cells with tumor necrosis factor $\alpha(\mathrm{TNF} \alpha)$ or FAS ligand, respectively, led to non-proteasomal degradation of IкB $\alpha$ and induction of apoptosis. IKK $\beta$, on the other hand, was not localized to the mitochondria. To date, most studies of NFKB in platelets have involved the use of IKK $\beta$ inhibitors and IKK $\beta$ knockout mice. Investigations in platelets centering on the role of IкB $\alpha$ and $\mathrm{p} 65$, in lieu of IKK $\beta$, may reveal novel apoptotic regulatory elements in platelets.

A second intriguing possibility is the role of $14-3-3 \beta$ in regulating mRNA stability in platelets. $14-3-3 \beta$ is a highly conserved protein that binds AU-rich elements (ARE) on mRNA, leading to destabilization of mRNA (29). Phosphorylation of 14-3-3 $\beta$ by IKK results in the release of a 14-3-3 $\beta$-tritetraprolin complex from the mRNA, thus preventing its destabilizing effects (30). This is interesting in light of the fact that platelets contain mRNA, which can be translated upon stimulation (31) Furthermore, 14-3-3 proteins can interact with p 65 and $\mathrm{I} \kappa \mathrm{B} \alpha$ to facilitate the export of p65 from the nucleus. As proteomic data show that human platelets

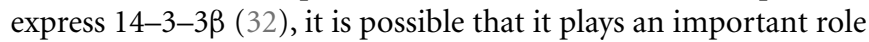
in regulating mRNA stability or NFKB signaling in the anucleate platelet.

\section{PPAR $\gamma$ IN PLATELETS}

Peroxisome proliferator-activated receptor $\gamma(\operatorname{PPAR} \gamma)$ is a ligandactivated transcription factor that is important in the regulation of lipid and glucose metabolism and is essential for fat production. Inactive PPAR $\gamma$ is localized to the cytoplasm of nucleated cells complexed with co-repressors. Upon ligand binding, the co-repressors dissociate, leading to a conformational change in $\operatorname{PPAR} \gamma$, allowing dimerization with retinoid X receptor $\alpha(\operatorname{RXR} \alpha)$ (33). This heterodimeric complex then acts as a scaffold for the recruitment of coactivator proteins, and $\operatorname{PPAR} \gamma$-dependent gene transcription commences. Our group discovered that human and mouse platelets express functional PPAR $\gamma$ protein that is regulated by activation or treatment with PPAR $\gamma$ ligands (34).

\section{PPAR $\gamma$ LIGANDS ARE CARDIOPROTECTIVE}

Thiazolidines (TZDs) are a class of oral antidiabetic drugs that exert their insulin-sensitizing actions through activation of $\operatorname{PPAR} \gamma$. In addition to regulating glucose homeostasis, TZDs, such as rosiglitazone, pioglitazone, and troglitazone, have potent antiinflammatory properties (35). Type II diabetics taking TZDs have improved glucose metabolism, decreased markers of inflammation, and improved cardiovascular health. Much of this can be attributed to the beneficial actions of TZDs on vascular cells and both direct and indirect actions on circulating platelets. Platelets from type II diabetics exhibit a more activated phenotype and are hyper-responsive to agonist $(36,37)$. These changes include increased platelet numbers and mean platelet volume (MPV), which may indicate alterations in megakaryocyte function or increased platelet turnover (38). Additionally, platelets from type II diabetics have enhanced surface expression of the collagen receptor (GPVI) and the fibrinogen receptor ( $\alpha \operatorname{IIb} \beta 3$ ), leading to increased adhesiveness and aggregation (39). Plasma from type II diabetics contains higher levels of the platelet-derived inflammatory mediators, soluble CD40L (sCD40L), soluble P-selectin (sP-selectin), and C-reactive protein $(40,41)$. Dsyregulated platelet function in type II diabetics is likely due to both inherent changes in the platelet and decreased prostaglandin $\mathrm{I}_{2}\left(\mathrm{PGI}_{2}\right)$ and nitric oxide $(\mathrm{NO})$ production from endothelial cells, which exert potent anti-platelet effects.

Numerous studies have demonstrated that TZDs beneficially regulate cardiovascular function in type II diabetics. They have consistently been shown to reduce the elevated levels of plasminogen activator inhibitor 1 (PAI-1) (42-44). PAI-1 rapidly binds and inactivates tissue plasminogen activator, thus preventing fibrinolysis and increasing thrombotic risk. Additionally, TZDs reduce markers of cardiovascular disease, which are typically elevated in type II diabetics, including C-reactive protein, serum amyloid A, fibrinogen, and matrix metalloproteinase 9 (45-49). Many of these beneficial changes can be attributed to improved glucose metabolism and restored vascular and endothelial homeostasis, although similar results can be seen in non-diabetic patients (50).

\section{PPAR $\gamma$ LIGANDS IMPROVE PLATELET FUNCTION IN TYPE II DIABETIC}

Consistent with their ability to reduce thrombotic risk, TZDs reduce markers of platelet activation. Rosiglitazone monotherapy decreased plasma sCD40L and P-selectin levels $(51,52)$. These data suggest that TZDs can directly or indirectly reduce platelet activation in type II diabetics. Supporting these findings, Khanolkar et al. demonstrated that patients receiving rosiglitazone and metformin had a significantly greater reduction in platelet aggregation compared to patients receiving gliclazide and metformin (53). Similarly, a second study found that pioglitazone in combination with metformin improved platelet function to a greater degree than glimepriride and metformin (49). A major unanswered question from these studies is whether TZDs improve cardiovascular health secondary to improved lipid metabolism or due to the anti-inflammatory actions of PPAR $\gamma$ stimulation. For example, macrophages, which play a key role in atherosclerosis, efflux cholesterol and are less inflammatory in response to PPAR $\gamma$ activation. In an attempt to investigate the insulin-sensitizing independent 
effects of TZDs, non-diabetic patients with coronary artery disease were treated with TZDs for 12 weeks. In this setting, TZDs reduced the inflammatory markers, C-reactive protein, tumor necrosis factor $\alpha(\mathrm{TNF} \alpha)$, and interleukin-6 (IL-6) $(50,54)$. Additionally, circulating platelet activity was dampened, as evidenced by fewer P-selectin positive platelets, suggesting an important role for the anti-inflammatory actions of PPAR $\gamma$.

\section{PPAR $\gamma$ LIGANDS DAMPEN PLATELET FUNCTION FROM HEALTHY DONORS}

Due to the global effects of TZDs, it is difficult to tease out indirect actions from potential direct effects of TZDs on platelet function. However, many recent studies have aimed to elucidate the direct effects of TZDs on platelet function. Our lab was the first to show that human platelets and megakaryocytes express functional PPAR $\gamma$ (55). The PPAR $\gamma$ ligands $15 \mathrm{~d}-\mathrm{PGJ}_{2}$ and rosiglitazone potently inhibit thrombin-induced CD40L surface expression and thomboxane $\mathrm{B}_{2}\left(\mathrm{TXB}_{2}\right)$ production and dampen ADP-induced aggregation (56). Other studies have confirmed these findings and further demonstrated that rosiglitazone and $15 \mathrm{~d}-\mathrm{PGJ}_{2}$ inhibited collagen-induced aggregation and prevented P-selectin exposure in vitro and in vivo $(54,57)$. Utilizing the specific PPAR $\gamma$ antagonist, GW9662, these effects were partially mediated through PPAR $\gamma$ in platelets from healthy donors (58). Moreover, pioglitazone was protective in a mouse model of thrombosis $(57,59)$. Similarly, using platelets from type II diabetics, which are hyperresponsive to agonist, rosiglitazone reduced aggregation and mediator release $(36,60)$. These data support the hypothesis that TZDs can regulate platelet function by directly acting on platelet PPAR $\gamma$.

Interestingly, PPAR-independent pathways are evident upon treatment with some ligands. $15 \mathrm{~d}_{-} \mathrm{PGJ}_{2}$ is an electrophilic compound that is known to form adducts with other cellular proteins, and could explain some of the PPAR-independent effects (61). Most interestingly, the mechanism of troglitazone differs from that of the structurally similar TZD, pioglitazone, in platelets. Although troglitazone and pioglitazone decreased platelet activation in vivo, only troglitazone directly inhibited platelet aggregation in vitro (62). However, in this study, only $1 \mu \mathrm{M}$ of each TZD was examined for their effects on platelet function. In some cell systems, troglitazone is more potent than pioglitazone, despite having a higher $\mathrm{EC}_{50}$ for binding PPAR $\gamma$ and this may also be the case in platelets (63). It is possible that higher concentrations of pioglitazone would exhibit similar effects as troglitazone. Another possibility is that there may be PPAR-independent effects or differential signaling of PPAR $\gamma$ in human platelets. Clinical data points to some PPAR-independent actions of TZDs as pioglitazone has been shown to decrease the risk of myocardial infarction and stroke in type II diabetics, while rosiglitazone had no effect and may actually increase the relative risk (64).

\section{SIGNALING MECHANISM OF PPAR $\gamma$ IN PLATELETS}

Differential signaling of PPAR $\gamma$ is not an unprecedented finding, as PPAR $\gamma$ is known to recruit various co-activators after stimulation with different ligands. Although most TZDs bind identical binding pockets in PPAR $\gamma$, their biological profiles are distinct (65, 66). This is in part due to differential recruitment of co-activators, but also possibly due to variations in availability of cofactors. In cell-based systems, PPAR $\gamma$ ligands can act as partial agonists in some cell types and full agonists in others (67). Additionally, different PPAR $\gamma$ ligands can recruit different co-activators in the same cell type, leading to different outcomes (68-70). These differences likely explain many of the adverse effects observed with some TZDs in clinical trials. Although still poorly understood, differential binding and recruitment of cofactors may explain the complex and sometimes contradictory actions of PPAR $\gamma$ in platelets, although no studies have evaluated this role of PPAR $\gamma$ in platelets to date.

Although a transcription factor, PPAR $\gamma$ has been shown to serve many other important non-genomic roles in platelets and nucleated cells (Figure 2). Specifically in platelets, collagen stimulation results in PPAR $\gamma$ recruitment to the GPVI signalosome and interacts with the adapter molecule, Syk (71). As a result, linker of activated T cells (LAT) is recruited and forms a complex with Syk and PPAR $\gamma$. In this setting, PPAR $\gamma$ appears to be necessary for enhancement of GPVI-mediated activation as treatment with PPAR $\gamma$ antagonists only partially blocks phosphorylation of LAT and the downstream targets phospholipase C $\gamma$ (PLC $\gamma)$, PI3K, and Akt. Interestingly, several other groups have demonstrated that cytosolic platelet PPAR $\gamma$ is released into the supernatants and in platelet-derived microparticles rapidly upon activation, leaving very low levels of PPAR $\gamma$ in the activated platelets $(34,72)$. This may suggest that early signaling

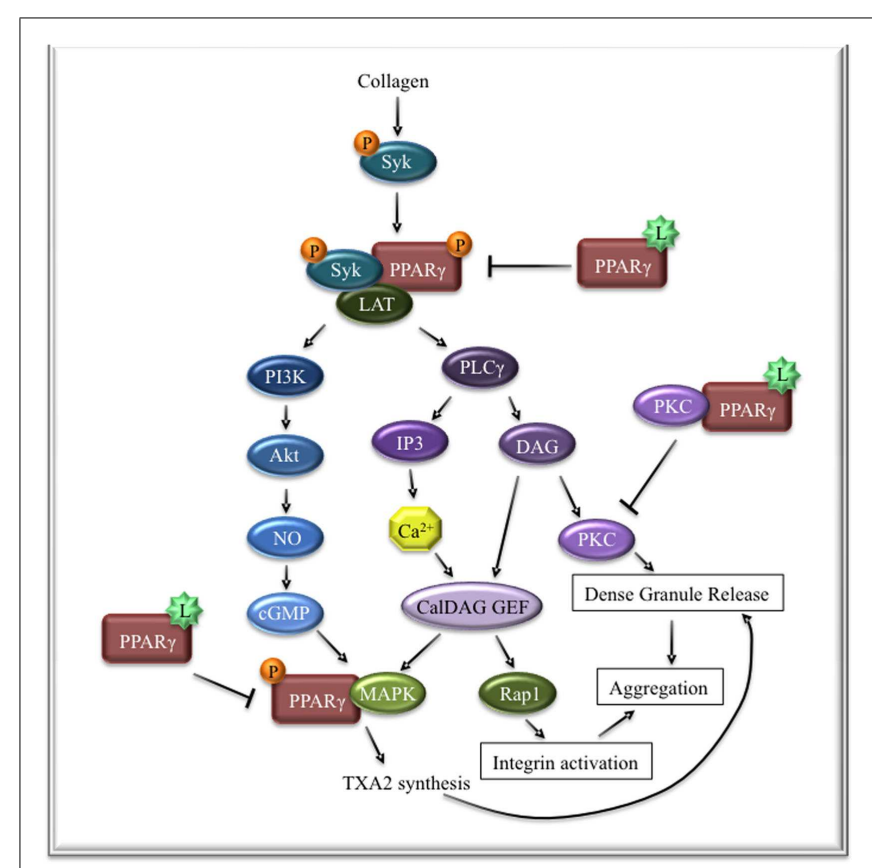

FIGURE 2 |The role of PPAR $\boldsymbol{\gamma}$ in collagen signaling in platelets. GPVI stimulation with collagen leads to the recruitment and activation of Syk. Syk recruits and phosphorylates PPAR $\gamma$, which in turn leads to the recruitment of LAT, resulting in enhanced signal transduction downstream of GPVI. PPAR $\gamma$ ligands prevent the interaction of PPAR $\gamma$ with the Syk signaling complex, which is necessary for enhanced signaling of Syk and LAT. Ligand-bound PPAR $\gamma$ can also interact with PKC $\alpha$, preventing it from mediating dense granule release. Lastly, ligand-activated PPAR $\gamma$ prevents PPAR $\gamma$ phosphorylation and interaction with MAPK, an essential downstream mediator of collagen signaling. 
roles of PPAR $\gamma$ include recruitment to the LAT/Syk signaling complex, which results in its packaging and export into microparticles, possibly due to its proximity to the cell membrane. Alternatively, there may be different pools of PPAR $\gamma$ that could have different subcellular localization patterns. It is not known whether platelets contain an unknown endogenous PPAR $\gamma$ ligand that plays a role in this signaling pathway. However, exogenous treatment of activated platelets with PPAR $\gamma$ ligands inhibit its interaction with the LAT/Syk signaling complex and reduces the amplitude of the signal, thus reducing aggregation and mediator release. Similarly, PPAR $\gamma$ ligands also blunt release of PPAR $\gamma$ into the supernatants and platelet-derived microparticles (34).

Separate studies have suggested that PPAR $\gamma$ interacts with ERK and p38 MAPK, which are common downstream mediators of platelet activation, leading to granule secretion (73). Stimulation of human platelets with collagen led to phosphorylation of PPAR $\gamma$ and its subsequent association with p-ERK and p38 MAPK. Treatment with PPAR $\gamma$ ligands prevented these interactions, reducing granule release. Similarly, PPAR $\gamma$ has been shown to interact with $\mathrm{PKC} \alpha$ in platelets in response to PPAR agonists, consequently reducing the activation of $\mathrm{PKC} \alpha$ (74). Although complex, there is sufficient evidence to suggest that PPAR $\gamma$ plays an important role in platelet signaling. PPAR $\gamma$ knockout mice are embryonic lethal; thus, a megakaryocyte and platelet-specific PPAR $\gamma$ knockout mouse model would be invaluable in determining the biologic role of PPAR $\gamma$ in platelets. As platelets do not contain a nucleus, any genomic deletion of PPAR $\gamma$ in platelets must also be deleted in the parent megakaryocyte. Therefore, changes in platelet function in these mice could be due to the loss of PPAR $\gamma$ in the platelet or megakaryocyte. Our group has recently shown that overexpression of PPAR $\gamma$ in a megakaryocyte cell line resulted in enhanced platelet production upon stimulation with a PPAR $\gamma$ ligand (72). These data suggest that PPAR $\gamma$ may play an important role in platelet production from megakaryocytes and could potentially convolute findings from megakaryocyte and platelet-specific PPAR $\gamma$ knockout mice.

\section{$\operatorname{PPAR} \beta / \delta$}

$\mathrm{PPAR} \beta / \delta$ is broadly expressed and plays an important role in skeletal muscle where it regulates cellular proliferation, differentiation, and fatty acid catabolism (75). Similar to PPAR $\gamma, \operatorname{PPAR} \beta / \delta$ is found in human and mouse platelets and PPAR $\beta / \delta$ ligands inhibit platelet function (76). Treatment with the specific PPAR $\beta / \delta$ ligand, GW501516, significantly increased cAMP levels in mouse platelets and prevented aggregation (77). Utilizing platelets from $\mathrm{PPAR} \beta / \delta$ knockout mice, the increase in cAMP was shown to be specific to $\mathrm{PPAR} \beta / \delta$ signaling, as cAMP levels in knockout platelets were drastically lower in response to ligand. Interestingly, no difference in aggregation was observed between knockout and control platelets treated with GW501516, suggesting that the inhibition of platelet aggregation by GW501516 occurs independent of $\operatorname{PPAR} \beta / \delta$. Furthermore, no differences were observed between knockout and control platelets' ability to produce cAMP or aggregate in response to ADP in the absence of PPAR $\beta / \delta$ ligand. This indicates that $\mathrm{PPAR} \beta / \delta$ in platelets may require ligand binding to exert its inhibitory effects on platelet function. Nevertheless, these data demonstrate that PPAR $\beta / \delta$ is capable of signaling in platelets, although the physiologic relevance remains unclear at this point.

One possible mechanism by which PPAR $\beta / \delta$ dampens platelet activation may involve the endogenous antithrombotic molecule, prostacyclin $\mathrm{I}_{2}\left(\mathrm{PGI}_{2}\right)$. $\mathrm{PGI}_{2}$ is produced by endothelial cells and is reported to be a ligand for PPAR $\beta / \delta(78)$, although this has not been proven in platelets. Previous studies have shown that $\mathrm{PGI}_{2}$ can synergize with endothelial-derived $\mathrm{NO}$ to inhibit platelet aggregation in response to variety of agonists through a mechanism involving increased cAMP (76). Another possible mechanism of action of PPAR $\beta / \delta$ in platelets may involve modulation of PKC $\alpha$ function. Treatment of human platelets with GW501516 induced association of PPAR $\beta / \delta$ with PKC $\alpha$ in a dose-dependent manner (77). PKC $\alpha$ has been shown to positively regulate platelet adhesion, a function that was dampened with $\mathrm{PPAR} \beta / \delta$ activation. Overall, very little is known about the biological significance and mechanism of PPAR $\beta / \delta$ in platelets, although the available data suggest a role in inhibiting platelet activation.

\section{PPAR $\alpha$}

$\operatorname{PPAR} \alpha$ is a major regulator of fatty acid homeostasis and inflammation. It is highly expressed in brown adipose tissue, liver, kidney, heart, and skeletal muscle (75). PPAR $\alpha$ agonists are used as a treatment for elevated plasma lipid levels and for their ability to increase the uptake of fatty acids and improve the high-density lipoprotein (HDL) to low-density lipoprotein (LDL) ratio. Little is known about the function of PPAR $\alpha$ in regulating hemostasis, but its presence was recently discovered in platelets. Statins and fibrates are PPAR $\alpha$ agonists and are widely prescribed for the prevention of coronary artery disease and atherosclerosis, thus reducing the risk of thrombotic events (74). In addition to their effects on lipid metabolism, statins and fibrates have been shown to activate PPAR $\alpha$ (79). Specifically, fenofibrate decreased agonistinduced platelet activation and increased bleeding times in mice (74). Fenofibrate's ability to inhibit platelet aggregation was abolished in the presence of a specific PPAR $\alpha$ antagonist. Additionally, bleeding times in PPAR $\alpha$ knockout mice were not affected by treatment with fenofibrate, unlike control mice. Interestingly, the baseline bleeding times in PPAR $\alpha$ knockout mice were longer than control mice, suggesting an additional role for PPAR $\alpha$ in maintaining hemostasis. Due to the usage of PPAR $\alpha$ global knockout mice, it is unclear whether this difference was due to platelet-specific or multivariate effects. Although the mechanisms of action of PPAR $\alpha$ in platelets have not been thoroughly investigated, some evidence suggests that it may regulate $\operatorname{PKC} \alpha$ activity, similar to PPAR $\gamma$ and $\mathrm{PPAR} \beta / \delta(80)$.

\section{NON-GENOMIC FUNCTIONS OF PPARS: LESSONS FROM NUCLEATED CELLS}

The wide use of PPAR ligands in the clinic has led to the discovery of numerous pleotropic effects of these compounds. These include PPAR-dependent, non-genomic actions in addition to PPAR-independent signaling of ligands $(81,82)$. The PPARindependent signaling mechanisms of PPAR ligands will not be discussed here, but these effects must be kept in mind when interpreting data investigating the effects of PPAR ligands on platelet function. In fact, these likely play an important role in regulating 
platelet function, perhaps through affecting mitochondrial activity, as many effects of PPAR ligands in platelets cannot be reversed using PPAR antagonists. Additionally, many PPAR ligands, such as unsaturated fatty acids, can cross-react with all PPAR isoforms at higher concentrations, further complicating the interpretation of these findings (83). It may be possible to generate useful hypotheses about how PPARs signal in platelets based upon similar studies in nucleated cells.

\section{PPAR $\gamma-P K C \alpha$ CROSSTALK}

In human epithelial colorectal adenocarcinoma cells, PPAR $\gamma$ has been shown to regulate $\mathrm{NFKB}$ activity in a non-genomic fashion involving their direct association (84). In this model, PPAR $\gamma$ bound to $\mathrm{p} 65$ in the nucleus, resulting in export of both proteins to the cytoplasm. Consequently, cytoplasmic localization of NFкB prevented its proinflammatory transcription-dependent effects. It is possible that PPAR $\gamma$ can also physically interact with p65 in platelets. This interaction could inhibit NFאB activity in platelets, which would exert anti-inflammatory and anti-platelet effects. $\operatorname{PPAR} \gamma$ has also been shown to form a direct interaction with PKC $\alpha$ upon stimulation with various PPAR $\gamma$ ligands in macrophages (85). The physical association of PKC $\alpha$ with PPAR $\gamma$ prevented PKC $\alpha$ translocation to the membrane and subsequent degradation. However, in this system PPAR $\gamma$ was only able to negatively regulate $\mathrm{PKC} \alpha$ activation in response to low-dose PMA stimulation. This suggests that the inhibitory effect of PPAR $\gamma$ can be overridden with stronger stimulation.

\section{PPAR $\alpha-P K C \alpha$ CROSSTALK}

Interestingly, PPAR $\alpha$ has also been shown to directly interact with $\mathrm{PKC} \alpha$ in macrophages (86). In response to LPS stimulation, PKC $\alpha$ bound and phosphorylated PPAR $\alpha$. However, in the presence of the PPAR $\alpha$ ligand, simvastatin, PPAR $\alpha$ no longer bound PKC $\alpha$ and consequently was able to transrepress NFKB activation. In this model, PKC $\alpha$ likely acts to deactivate PPAR $\alpha$ 's inhibitory actions on the proinflammatory NFKB signaling. This may represent a mechanism by which PPAR $\alpha$ ligands, such as statins, exert potent and rapid anti-inflammatory actions. Although the interaction of PPAR $\alpha$ with PKC $\alpha$ was postulated to negatively regulate PPAR $\alpha$ 's function in this system, it is possible that this complex serves additional and possibly proinflammatory functions. Similarly, these data suggest that in platelets, ligand-induced activation of PPAR $\alpha$ may function differently than phosphorylation-induced activation, resulting in different or possibly contradictory actions. This may even explain the discrepancy between the bleeding phenotype observed in PPAR $\alpha$ knockout mice, while control mice also had increased bleeding times with $\operatorname{PPAR} \alpha$ activation. Perhaps, PPAR $\alpha$, independent of ligand, acts as a positive regulator of platelet hemostatic function by enhancing activation of PKC $\alpha$,

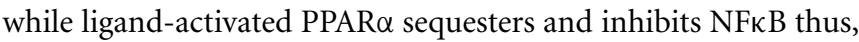
negatively regulating platelet activation (Figure 3).

\section{PPAR $\gamma$ AND PPAR $\alpha$ REGULATE MAP KINASES}

Another possible role of PPAR $\alpha$ in platelets involves regulation of MAP kinases. In T cells, PPAR $\alpha$ was shown to inhibit p38 MAPK

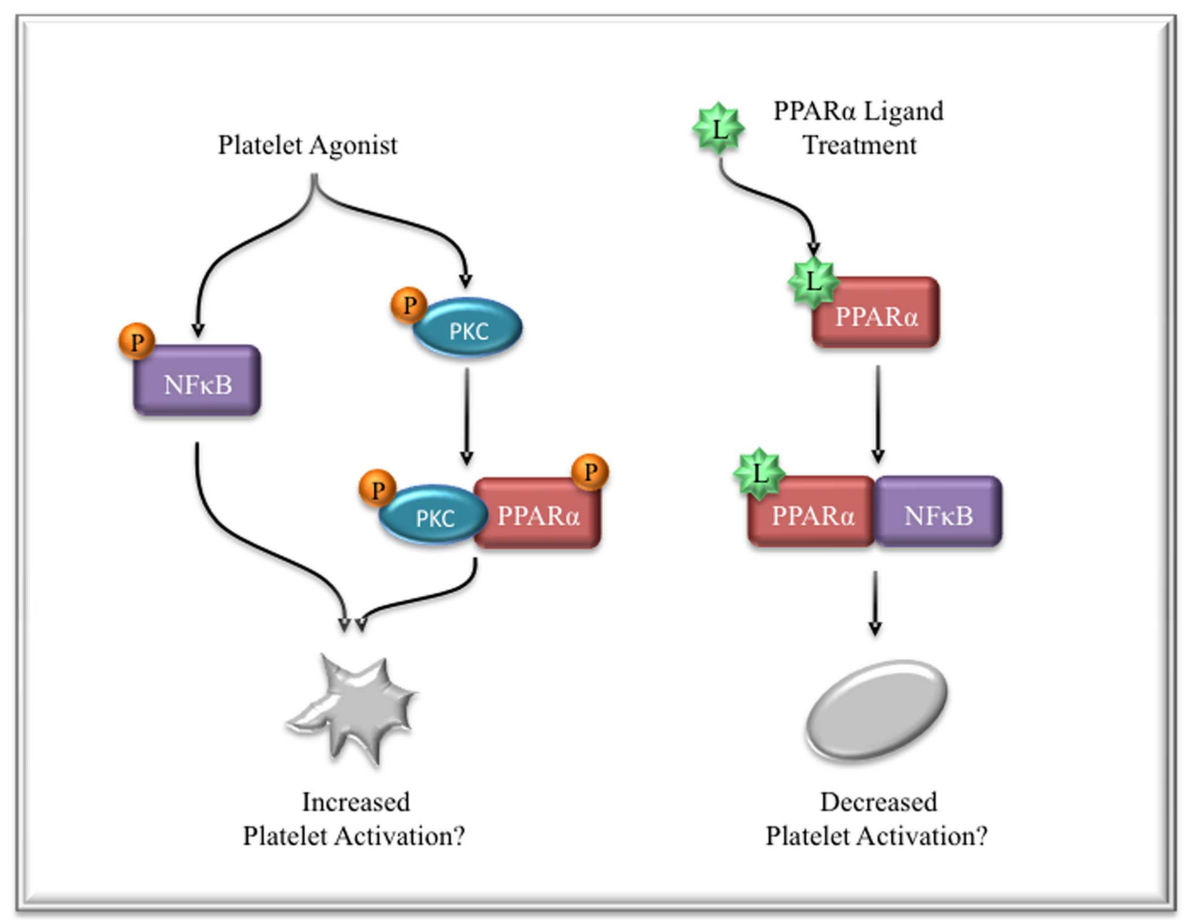

FIGURE 3 | Possible mechanism of PPAR $\alpha$ and NFKB regulation in platelets. Platelet activation leads to NFKB phosphorylation and activation, which potentiates activation signals. PKC $\alpha$ is also phosphorylated and activated in response to stimulation. This may lead to an interaction between
PPAR $\alpha$ and PKC $\alpha$, leading to increased activation. Treatment with PPAR $\alpha$ ligands prevents PPAR $\alpha$ binding to $P K C \alpha$, but instead enhances its interaction with $N F_{\kappa} B$, thus functionally sequestering PPAR $\alpha$ and $N F_{\kappa} B$ from participating in activation signaling. 
activation, but only in the absence of ligand (87). Additionally, this regulation of p38 MAPK appeared to be independent of direct interaction with $\operatorname{PPAR} \alpha$, but likely required an unknown secondary mediator. Activation of p38 MAPK occurs early in platelet activation, albeit transiently, to induce granule release that stimulates the second wave of aggregation $(88,89)$. Subsequent ligand binding to $\alpha \operatorname{IIb} \beta 3$ downregulates active p38 MAPK (90). Perhaps, $\operatorname{PPAR} \alpha$ mediates the regulation of p38 MAPK in these conditions or possibly under shear stress, whereby p38 MAPK mediates adhesion in flow.

PPAR $\gamma$ has also been shown to regulate MAPK pathways in nucleated cells through non-genomic mechanisms (91). PPAR $\gamma$ reversibly interacts with MEK1 via its AF2 domain, resulting in export from the nucleus to the cytoplasm. This corroborates evidence suggesting that PPAR $\gamma$ ligands regulate downstream ERK signaling (92). Interestingly, PPAR $\gamma$ activation led to rapid ERK phosphorylation in human prostate cancer cells, vascular smooth muscle cells, and human microvascular endothelial cells, but inhibited ERK activation in adrenocortical cancer cells (93-95). Similarly, PPAR $\gamma$ enhanced ERK activation in rabbit renal cortex cells, but had no effect in mouse cells (96). These data suggest cell type-specific and species-specific effects of PPAR $\gamma$, possibly through availability of different co-activators. The effects of PAPR $\gamma$ activation on the MEK/ERK pathway in platelets has not been investigated, but represents a promising avenue of further research.

\section{LIVER X RECEPTORS}

Liver $\mathrm{X}$ receptors (LXRs) are transcription factors that play key roles in cholesterol homeostasis by regulating genes, such as apolipoprotein $\mathrm{E}$ and cytochrome P450 $7 \alpha$-hydroxylase 1 (Cyp7a1) $(97,98)$. Recent studies have demonstrated that platelets express LXR $\beta$ and its ligands inhibited collagen-induced aggregation (99). Thrombin and fibrinogen-induced activation was affected to a lesser degree, requiring high doses of LXR ligands to exert comparable inhibitory effects. Collagen-induced Syk phosphorylation was strongly inhibited by pretreatment with LXR ligands, while LAT and PLC $\gamma$ phosphorylation were inhibited to a lesser degree, which could be explained by the high concentration of collagen used for activation $(50 \mu \mathrm{g} / \mathrm{mL})$. Interestingly, and opposite of the results seen with PPAR $\gamma$ (71), LXR ligands induced association of LXR with Syk and PLC $\gamma$. Moreover, stimulation of platelets with PPAR $\gamma$ or LXR ligands led to an association between the two transcription factors, which was diminished with higher concentrations of ligand. Taken together, these data suggest that LXR and PPAR $\gamma$ can physically interact in platelets and this may represent a novel regulatory mechanism of collagen-induced activation (Figure 4). In cell free systems, LXR $\beta$ was able to bind all three PPAR isoforms with different affinities (100). Moreover, different PPAR ligands altered the affinities of these interactions. For example, troglitazone inhibited PPAR $\gamma / \mathrm{LXR} \beta$ interactions, while GI262570, a PPAR $\gamma$ ligand with high binding affinity, had no effect on this interaction. This may help to explain why different

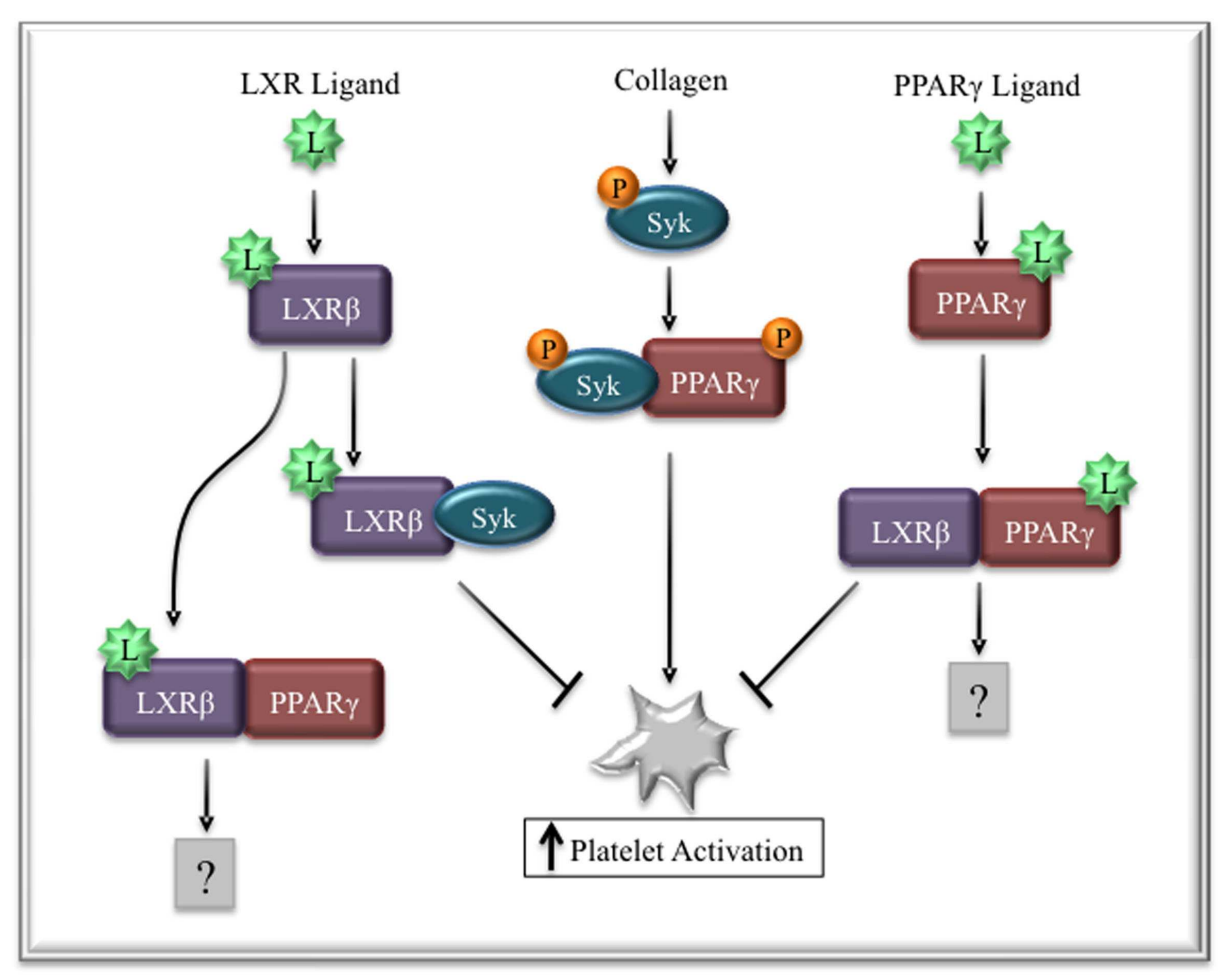

FIGURE 4 | Regulation of collagen signaling by LXR $\beta$ and PPAR $\boldsymbol{\gamma}$. Collagen signaling leads to the phosphorylation of Syk and PPAR $\gamma$. Ligand-activated LXR binds Syk, preventing its interaction with PPAR $\gamma$, thus decreasing platelet activation. Similarly, PPAR $\gamma$ ligands or LXR ligands can induce the interaction of PPAR $\gamma$ and $L X R$, reducing the availability of PAPR $\gamma$ to participate in collagen signaling. 
PPAR ligands exert different effects on platelet signaling and function.

\section{RETINOID X RECEPTORS}

Retinoid X receptors comprise a group of nuclear receptors that recognize vitamin A metabolites (101). The three different isoforms of RXRs $(\alpha, \beta$, and $\gamma)$ are expressed in different tissues, with RXR $\alpha$ and $\operatorname{RXR} \beta$ being fairly widely expressed and $\operatorname{RXR} \gamma$ is mainly expressed in skeletal muscle and heart tissue (102). $\operatorname{RXR} \alpha$ is the heterodimeric binding partner of $\operatorname{PPAR} \gamma$, which is essential for mediating the genomic effects of PPAR $\gamma$. Platelets express the RXR $\alpha$ and $\beta$ isoforms, but not $\operatorname{RXR} \gamma$, and RXRs immunoprecipitate with PPAR $\gamma$ in platelets. (103) Similar to PPAR $\gamma$ ligands, the RXR ligand, 9-cis-retinoic acid (9cRA), inhibited agonist-induced platelet activation. Interestingly, however, 9cRA preferentially inhibited ADP and U46619 (a thromboxane mimetic)-induced aggregation, but did not alter collagen-induced activation. This is surprising in light of the fact that PPAR $\gamma$ ligands dampen signaling through the collagen receptor (Figure 2), suggesting that RXR in platelets can signal non-genomically independent of PPAR $\gamma$. RXR $\alpha$ co-immunoprecipitated with Gq11 in resting platelets and this interaction was enhanced when platelets were stimulated with 9cRA. In this manner, ligand-bound RXR $\alpha$ may sequester $\mathrm{Gq}$ from its traditional role in propagating signals from G-protein coupled receptors, such as the ADP and thromboxane receptors.

\section{GLUCOCORTICOID RECEPTORS}

The glucocorticoid receptor (GR) is a nuclear hormone receptor that binds glucocorticoids, such as dexamethasone and prednisolone, resulting in an anti-inflammatory response (104). Human platelets express GR and differentially respond to its ligands (105). One study found that human platelets were less responsive to activation when treated with prednisolone, but not dexamethasone (106). Furthermore, the inhibitory effects of prednisolone on platelet function could be prevented by treatment with the GR antagonist, RU486. Interestingly, binding assays in human platelets revealed that both glucocorticoids could bind GR and increase its association with the chaperone protein, HSP90. In nucleated cells, ligand binding to GR causes HSP90 dissociation from the GR complex, which reveals its nuclear localization signal (107). However, the opposite effect was found in platelets, suggesting a different method of regulation. Moreover, a unique dimerization was identified in human platelets between GR and the mineralocorticoid receptor (MR), which can bind some of the same ligands as GR, such as dexamethasone. This may help to explain why dexamethasone affected platelet function differently from the more specific GR agonist, prednisolone. Additionally, mineralocorticoids activate PI3K, consistent with the finding that mineralocorticoid actions are associated with increased risk of vascular disease (108).

\section{ARYL HYDROCARBON RECEPTOR}

The aryl hydrocarbon receptor (AHR) is a well-known toxicantsensing receptor that also plays essential roles in immune function and hematopoiesis (109). Common AHR ligands include polycyclic aromatic hydrocarbons, lipoxin A4, and 2,3,7,8tetrachlorodibenzo- $p$-dioxin (TCDD). Mouse platelets express
AHR, which is known to play an important role in hematopoiesis and megakaryocyte development (110). Platelets from AHR knockout mice exhibit defective collagen signaling, with inhibited collagen-induced aggregation and spreading. Of note, platelets from AHR knockout mice had lower levels of the collagen receptor, GPVI, and undetectable levels of Vav proteins. Vav1 and Vav3 are activated downstream of many signaling pathways in platelets, and play a role in responding to collagen (111). Although the defects in platelet collagen signaling in AHR knockout mice are intriguing and may suggest an important role for this transcription factor in platelet biology, a more thorough investigation is needed. It is still unknown whether platelets respond to AHR ligands and whether they affect agonist-induced activation. Moreover, it is possible that the defects in collagen signaling in AHR knockout mice could be solely attributed to defective thrombopoiesis and altered platelet composition. Limited studies have evaluated the effects of AHR ligands in hemostasis. Polychlorinated biphenyls, which are non-specific AHR ligands, enhanced human platelet activation (112). Additionally, the specific AHR ligand, TCDD, was shown to induce thrombocyte aggregation in zebrafish (113). This can likely be attributed to its non-genomic actions in thrombocytes, as these effects were seen as early as 30 min post-treatment. Further research investigating the effects of AHR activation in platelets may reveal novel actions of environmental toxicants on hemostasis and cardiovascular risk.

The AHR has been shown to form a complex with the p65 subunit of NFkB in breast cancer cells (114). Furthermore, this interaction was found to be functionally relevant, resulting in proliferation and tumorigenesis. Additional roles for the AHR in regulation of NFKB signaling have been shown by our group in fibroblasts $(115,116)$. We found that absence of the AHR coincided with decreased expression of the non-canonical NFKB member, RelB. Signal-specific phosphorylation of RelB targets it for proteosomal degradation. It is possible that physical association between the AHR and RelB prevents its proteosomal degradation and allows it to exert anti-inflammatory effects, similar to its regulation in $\mathrm{T}$ cells (117).

\section{SIGNAL TRANSDUCER AND ACTIVATOR OF TRANSCRIPTIONS}

The signal transducer and activator of transcription (STAT) family of proteins were some of the first identified functional transcription factors in platelets (118). Human platelets express STATs 1, 3, and 5 , which traditionally play a role in transducing signals from cytokine receptors to elicit an immune response (119). Early on, it was known that thrombopoietin could act on human platelets and this resulted in STAT3 phosphorylation, although the biological significance was unclear. Recently, the role of STAT3 in platelet signaling has been investigated more thoroughly, uncovering an important role for it in GPVI signaling (120). Pharmacologic inhibition of STAT3 signaling or dimerization resulted in a hyporesponsive phenotype to low-dose collagen activation. Additionally, platelets from platelet and megakaryocyte-specific STAT3 knockout mice had lower levels of collagen-induced aggregation, decreased P-selectin expression, and slowed thrombus formation. Interrogation of the signaling cascade revealed that STAT3 was activated by JAK2, in the same manner as in nucleated cells. 
Traditionally, STAT3 homodimerizes upon phosphorylation by JAK2, then translocates to the nucleus where it acts as a traditional transcription factor. However, in platelets, phosphorylation of STAT3 by JAK2 resulted in dimerization and activation of PLC $\gamma$. Syk was found to be an upstream activator of this pathway and was complexed with STAT3 and PLC $\gamma$ after activation with collagen (121). These data suggest that STAT3 plays an important regulatory role in platelet activation downstream of collagen and thrombopoietin signaling.

\section{THE DIVERGENT ROLES OF TRANSCRIPTION FACTORS}

The investigation of transcription factors in platelets has often led to convoluted and sometimes contradictory findings. This can most clearly been seen in the evaluation of the roles of PPAR $\alpha$ in platelets. In this case, $\operatorname{PPAR} \alpha$ appears to play an important role in platelet activation, but has the opposite effect in the presence of a PPAR $\alpha$ ligand (74). Additionally, phosphorylated PPAR $\gamma$ positively regulates collagen signaling, while ligand-bound PPAR $\gamma$ inhibits activation (71). These data support the hypothesis that ligand-induced activation of transcription factors can function differently than phosphorylation-induced activation (Figure 3).

\section{MICROPARTICLES AS TRANSPORTS OF TRANSCRIPTION FACTORS}

Microparticles are plasma membrane-derived vesicles ranging in diameter from 0.1 to $1 \mu \mathrm{m}$ that are present at levels of approximately $5-50 \mu \mathrm{g} / \mathrm{mL}$ in blood plasma (122). Platelets and megakaryocytes are the primary source of microparticles in the blood circulation (about 80\%), whereas other microparticles are derived from erythrocytes, endothelial cells, and granulocytes (122-124). Since their discovery, the role of platelet microparticles in coagulation was evident, and later was supported by identification of tissue factor expression (123) and a phosphatidylserinerich outer membrane (125) that binds coagulation factors to aid in their assembly and enzymatic processing. Microparticles are produced from resting cells, during apoptosis or during cell activation, likely resulting in different internal and surface composition. Microparticles were shown to differ in composition between human samples and between microparticle size classes $(126,127)$. Packaging mechanisms for microparticles have not yet been identified and such studies are crucial for the understanding of microparticle influences on their environment. Whether microparticle packaging is a passive or active process, increased proximity of mediators to the cell plasma membrane would likely increase their chances of becoming encapsulated by the released microparticles.

\section{MICROPARTICLE FUNCTIONS AND ROLES IN INFLAMMATION}

Microparticles are postulated to have several means to influence their environment. Burger et al. described their ability to (1) promote coagulation, (2) scavenge NO, (3) generate reactive oxygen species, (4) cleave cellular surface proteins via metalloproteinases, (5) signal cells via surface proteins, and (6) deliver cargo via transfer of membrane and internal contents (128). Additionally, microparticles are postulated to contribute to, and sometimes exacerbate inflammation. It is likely that surface interactions and the less studied delivery of internal microparticle contents are both contributing to the influences of microparticles on their environment.

\section{TRANSCELLULAR COMMUNICATION}

Circulating microparticles can interact with other blood cells they encounter, such as leukocytes, lymphocytes, platelets, and with endothelial cells. Specific modes of cell-microparticle interactions include surface receptor signaling, plasma membrane fusion, or internalization of microparticles (129). The fusion of platelet microparticle membranes to target cell membranes was demonstrated to transfer the surface protein CXCR4 to cells causing recipient cell susceptibility to human immunodeficiency virus infection (130). Membrane fusion or internalization of microparticles could also cause microparticle internal composition to be transferred into the recipient cell cytoplasm. Lipids (131), RNA, and protein (129) have been seen to be delivered in this fashion, and multiple examples of each are reviewed by Mause and Weber (132). Arachidonic acid is a lipid mediator delivered by platelet microparticles that can be further processed into thromboxane $\mathrm{A}_{2}$ by recipient platelets and contribute to their activation (131). Overall, platelet microparticles contain various mediators that can be delivered to surrounding cells to impact their function.

\section{TRANSCRIPTION FACTORS IN MICROPARTICLES AND ROLES IN TRANSCELLULAR COMMUNICATION}

The influence of microparticles on recipient cell function is based on microparticle composition. Not surprisingly, blood microparticle protein composition was found to be highly variable between healthy humans (127). Our work showed that platelet microparticles contain transcription factors, such as PPAR $\gamma$, derived from parent cells (34). Furthermore, proteomic analysis has led to the discovery of three other transcription factors in platelet microparticles, RuvB-like 2, STAT3, and STAT5A (133).

Transcription factors are transported from cells through microparticles and retain function within the recipient cells (34, 72). Our lab was the first to show this ability with platelet-derived microparticles delivering functional PPAR $\gamma$ to THP-1 monocytes, detected through an electrophoresis mobility gel shift assay (134). We have since developed a novel platform technology to engineer microparticles through overexpression of PPAR $\gamma$ in platelet and megakaryocyte-derived microparticles obtained from the cultured megakaryoblastic cell line, Meg-01 cells. We showed that these engineered microparticles could be taken up by THP-1 monocytes, and that the transferred PPAR $\gamma$ was functional within recipients shown by induction fatty acid binding protein-4 (FABP4) expression, a unique PPAR $\gamma$-specific target gene (72) (Figure 5).

To identify the significance of the transferred PPAR $\gamma$ to recipient cells, we compared recipient cell responses incubated with microparticles that did or did not contain PPAR $\gamma$, to inflammatory stimuli (135). Monocytes that received PPAR $\gamma$-containing microparticles had decreased inflammatory mediator production compared to the control microparticles. PPAR $\gamma$ activation has been shown to induce cell differentiation $(136,137)$. Our work also supported the influence of PPAR $\gamma$ on monocyte differentiation as the cells receiving PPAR $\gamma$-containing microparticles became more adherent through increased integrin expression and fibronectin 


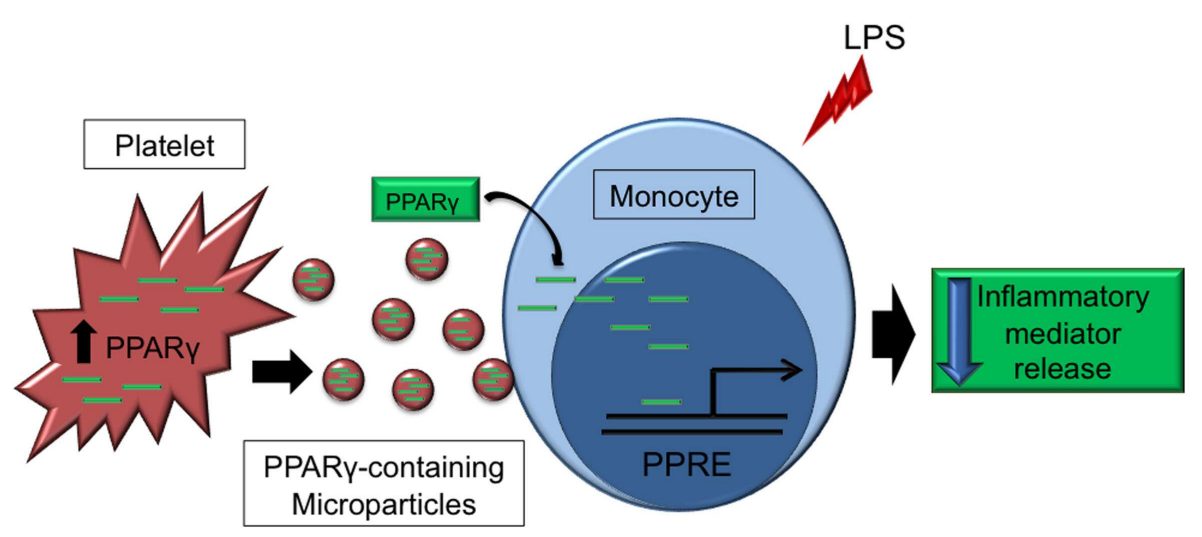

FIGURE 5 | Platelet microparticles as a method of transcellular delivery of transcription factors. Platelet-derived PPAR $\gamma$ is packaged into platelet microparticles, which can deliver intact PPAR $\gamma$ protein to target cells, such as monocytes. PPAR $\gamma$ can then bind to peroxisome proliferator response elements (PPRE) in the nucleus to affect transcription of target genes. Transfer of PPAR $\gamma$ to monocytes via microparticles has been shown to decrease LPS-induced inflammatory mediator release. production (135). These data support the notion that circulating microparticles could have a profound impact on inflammatory cells during responses to insult and injury. Specifically, the antiinflammatory PPAR $\gamma$ and proinflammatory NF- $\kappa$ B composition of microparticles could vastly dampen or heighten responses of recipient cells.

\section{DIAGNOSTIC AND THERAPEUTIC POTENTIAL OF MICROPARTICLES}

Measurements of microparticle abundance are becoming a more popular assessment of systemic inflammation. With current technology, it is easier and less expensive to measure microparticle number and surface composition rather than running entire microparticle proteomic studies with each patient sample. Microparticle number and surface phenotype have provided descriptive diagnostic tools indicative of disease severity. However, evaluation of the total protein composition of microparticles would tell an infinitely more detailed summary of patient health status. Particularly, looking at levels of the highly influential transcription factors within circulating microparticles would provide insight into the inflammatory state from the cells generating the microparticles as well as the potential inflammatory impact on recipient cells within the blood.

Delivery of platelet proteins such as PPAR $\gamma$ could have an antiinflammatory and/or pro-differentiation influence on activated cells via microparticles and act as a physiological means of quenching inflammation. Transcription factors would be among the most influential mediators to deliver to a cell, as they are capable of initiating transcripts of multiple downstream products that could influence numerous networks and pathways. Certain transcription factors may require signal or ligand activation to fully function in a microparticle delivery setting. In the case of PPAR $\gamma$, endogenous ligands such as $15 \mathrm{~d}-\mathrm{PGJ}_{2}$ and others may be present or synthesized. Whereas the components delivered by microparticles may be short-lived, their effects on the recipient cells may sometimes be permanent, such as inducing irreversible differentiation or death of recipient cells.
Overall, platelet microparticles are abundant and influential transcellular vesicles. They contain proteins, lipids, and RNA derived from their parent cells. Therefore, these circulating biomarkers provide insight into the cumulative activation and inflammatory state of all blood cell populations. Importantly, microparticles have repeatedly been shown to not just be cell byproducts but rather influential delivery mechanisms. Transportation of transcription factors to cells could influence several ongoing or initiate new pathways causing profound impacts within recipient cells. Transcellular communication involving transcription factors via platelet microparticles substantiates another possible key role of transcription factors presence in platelets.

\section{CONCLUSION}

Transcription factors play numerous important and previously unrecognized roles in regulating platelet function in a nongenomic manner. Additionally, transfer of intact and functional transcription factors to other cells via microparticles may serve as a novel regulatory mechanism for inflammation. The initial discovery of transcriptional regulatory elements in a particular protein does not exclude the possibility of non-genomic roles for that protein as well. The anucleate platelet can serve as an important model system to study non-genomic roles of transcription factors. Further elucidation of the non-genomic functions of transcription factors will yield important discoveries that have the potential to illuminate platelet biology and also help to explain the pleotropic effects of pharmaceuticals that target these pathways.

\section{ACKNOWLEDGMENTS}

This work was supported in part by ES001247, HL095467, T32AI007285, NS066801, T90 DE0 21985 and HL128129 a University of Rochester grant from Howard Hughes Medical Institute through the Med into Grad Initiative, and UL1RR024160 and UL1TR000042 from the National Center for Research Resources. The content is solely the responsibility of the authors and does not necessarily represent the views of NCRR or NIH. 


\section{REFERENCES}

1. Rondina MT, Weyrich AS, Zimmerman GA. Platelets as cellular effectors of inflammation in vascular diseases. Circ Res (2013) 112(11):1506-19. doi:10. 1161/CIRCRESAHA.113.300512

2. Morrell CN, Aggrey AA, Chapman LM, Modjeski KL. Emerging roles for platelets as immune and inflammatory cells. Blood (2014) 123(18):2759-67. doi:10.1182/blood-2013-11-462432

3. Garraud O, Hamzeh-Cognasse H, Pozzetto B, Cavaillon JM, Cognasse F. Benchto-bedside review: platelets and active immune functions - new clues for immunopathology? Crit Care (2013) 17(4):236. doi:10.1186/cc12716

4. Spinelli SL, Maggirwar SB, Blumberg N, Phipps RP. Nuclear emancipation: a platelet tour de force. Sci Signal (2010) 3(144):e37. doi:10.1126/scisignal. 3144 pe37

5. Chariot A. The NF-kappa B-independent functions of IKK subunits in immunity and cancer. Trends Cell Biol (2009) 19(8):404-13. doi:10.1016/jcb.2009. 05.006

6. Spinelli SL, Casey AE, Pollock SJ, Gertz JM, McMillan DH, Narasipura SD, et al. Platelets and megakaryocytes contain functional nuclear factor-kappaB. Arterioscler Thromb Vasc Biol (2010) 30(3):591-8. doi:10.1161/ATVBAHA.109. 197343

7. Malaver E, Romaniuk MA, D’Atri LP, Pozner RG, Negrotto S, Benzadón R, et al. NF-kappa B inhibitors impair platelet activation responses. J Thromb Haemost (2009) 7(8):1333-43. doi:10.1111/j.1538-7836.2009.03492.x

8. Gambaryan S, Kobsar A, Rukoyatkina N, Herterich S, Geiger J, Smolenski A, et al. Thrombin and collagen induce a feedback inhibitory signaling pathway in platelets involving dissociation of the catalytic subunit of protein kinase A from an NFkappaB-IkappaB complex. J Biol Chem (2010) 285(24):18352-63. doi:10.1074/jbc.M109.077602

9. Liu F, Morris S, Epps J, Carroll R. Demonstration of an activation regulated NF-kappa B/I-kappaBalpha complex in human platelets. Thromb Res (2002) 106(4-5):199-203. doi:10.1016/S0049-3848(02)00130-5

10. Chang CC, Lu WJ, Ong ET, Chiang CW, Lin SC, Huang SY, et al. A novel role of sesamol in inhibiting NF- $\kappa \mathrm{B}-$ mediated signaling in platelet activation. J Biomed Sci (2011) 18:93. doi:10.1186/1423-0127-18-93

11. Lee HS, Kim SD, Lee WM, Endale M, Kamruzzaman SM, Oh WJ, et al. A noble function of BAY 11-7082: inhibition of platelet aggregation mediated by an elevated cAMP-induced VASP, and decreased ERK2/JNK1 phosphorylations. Eur J Pharmacol (2010) 627(1-3):85-91. doi:10.1016/j.ejphar.2009.11.005

12. Chen WF, Lee JJ, Chang CC, Lin KH, Wang SH, Sheu JR. Platelet proteaseactivated receptor (PAR)4, but not PAR1, associated with neutral sphingomyelinase responsible for thrombin-stimulated ceramide-NF- $\mathrm{KB}$ signaling in human platelets. Haematologica (2013) 98(5):793-801. doi:10.3324/haematol.2012. 072553

13. Pierce JW, Schoenleber R, Jesmok G, Best J, Moore SA, Collins T, et al. Novel inhibitors of cytokine-induced IkappaBalpha phosphorylation and endothelial cell adhesion molecule expression show anti-inflammatory effects in vivo. J Biol Chem (1997) 272(34):21096-103. doi:10.1074/jbc.272.34.21096

14. Karim ZA, Zhang J, Banerjee M, Chicka MC, Al Hawas R, Hamilton TR, et al. IКB kinase phosphorylation of SNAP-23 controls platelet secretion. Blood (2013) 121(22):4567-74. doi:10.1182/blood-2012-11-470468

15. Hachem A, Yacoub D, Zaid Y, Mourad W, Merhi Y. Involvement of nuclear factor $\mathrm{\kappa B}$ in platelet CD40 signaling. Biochem Biophys Res Commun (2012) 425(1):58-63. doi:10.1016/j.bbrc.2012.07.049

16. Wei S, Wang H, Zhang G, Lu Y, An X, Ren S, et al. Platelet IкB kinase$\beta$ deficiency increases mouse arterial neointima formation via delayed glycoprotein Ib $\alpha$ shedding. Arterioscler Thromb Vasc Biol (2013) 33(2):241-8. doi:10.1161/ATVBAHA.112.300781

17. Cognasse F, Hamzeh-Cognasse H, Garraud O. [Platelets "toll-like receptor" engagement stimulates the release of immunomodulating molecules]. Transfus Clin Biol (2008) 15(4):139-47. doi:10.1016/j.tracli.2008.07.010

18. Berthet J, Damien P, Hamzeh-Cognasse H, Arthaud CA, Eyraud MA, Zéni F, et al. Human platelets can discriminate between various bacterial LPS isoforms via TLR4 signaling and differential cytokine secretion. Clin Immunol (2012) 145(3):189-200. doi:10.1016/j.clim.2012.09.004

19. Lu WJ, Lee JJ, Chou DS, Jayakumar T, Fong TH, Hsiao G, et al. A novel role of andrographolide, an NF-kappa B inhibitor, on inhibition of platelet activation: the pivotal mechanisms of endothelial nitric oxide synthase/cyclic GMP. J Mol Med (Berl) (2011) 89(12):1261-73. doi:10.1007/s00109-011-0800-0
20. Lu WJ, Lin KH, Hsu MJ, Chou DS, Hsiao G, Sheu JR. Suppression of NF$\kappa \mathrm{B}$ signaling by andrographolide with a novel mechanism in human platelets: regulatory roles of the p38 MAPK-hydroxyl radical-ERK2 cascade. Biochem Pharmacol (2012) 84(7):914-24. doi:10.1016/j.bcp.2012.06.030

21. Sambrano GR, Weiss EJ, Zheng YW, Huang W, Coughlin SR. Role of thrombin signalling in platelets in haemostasis and thrombosis. Nature (2001) 413(6851):74-8. doi:10.1038/35092573

22. Mazharian A, Roger S, Berrou E, Adam F, Kauskot A, Nurden P, et al. Proteaseactivating receptor- 4 induces full platelet spreading on a fibrinogen matrix: involvement of ERK2 and p38 and Ca2+ mobilization. J Biol Chem (2007) 282(8):5478-87. doi:10.1074/jbc.M609881200

23. Brill A, Chauhan AK, Canault M, Walsh MT, Bergmeier W, Wagner DD. Oxidative stress activates ADAM17/TACE and induces its target receptor shedding in platelets in a p38-dependent fashion. Cardiovasc Res (2009) 84(1):137-44. doi:10.1093/cvr/cvp176

24. Lee S, Andrieu C, Saltel F, Destaing O, Auclair J, Pouchkine V, et al. IkappaB kinase beta phosphorylates Dok1 serines in response to TNF, IL-1, or gamma radiation. Proc Natl Acad Sci U S A (2004) 101(50):17416-21. doi:10.1073/pnas.0408061101

25. Flevaris P, Li Z, Zhang G, Zheng Y, Liu J, Du X. Two distinct roles of mitogenactivated protein kinases in platelets and a novel Racl-MAPK-dependent integrin outside-in retractile signaling pathway. Blood (2009) 113(4):893-901. doi:10.1182/blood-2008-05-155978

26. García A, Senis YA, Antrobus R, Hughes CE, Dwek RA, Watson SP, et al. A global proteomics approach identifies novel phosphorylated signaling proteins in GPVI-activated platelets: involvement of G6f, a novel platelet Grb2binding membrane adapter. Proteomics (2006) 6(19):5332-43. doi:10.1002/ pmic.200600299

27. Cogswell PC, Kashatus DF, Keifer JA, Guttridge DC, Reuther JY, Bristow C, et al. NF-kappa B and I kappa B alpha are found in the mitochondria. Evidence for regulation of mitochondrial gene expression by NF-kappa B. J Biol Chem (2003) 278(5):2963-8. doi:10.1074/jbc.M209995200

28. Bottero V, Rossi F, Samson M, Mari M, Hofman P, Peyron JF. Ikappa balpha, the NF-kappa B inhibitory subunit, interacts with ANT, the mitochondrial ATP/ADP translocator. J Biol Chem (2001) 276(24):21317-24. doi:10.1074/jbc.M005850200

29. Gringhuis SI, García-Vallejo JJ, van Het Hof B, van Dijk W. Convergent actions of I kappa B kinase beta and protein kinase C delta modulate mRNA stability through phosphorylation of 14-3-3 beta complexed with tristetraprolin. $\mathrm{Mol}$ Cell Biol (2005) 25(15):6454-63. doi:10.1128/MCB.25.15.6454-6463.2005

30. Aguilera C, Fernández-Majada V, Inglés-Esteve J, Rodilla V, Bigas A, Espinosa L. Efficient nuclear export of p65-IkappaBalpha complexes requires 14-3-3 proteins. J Cell Sci (2006) 119(Pt 17):3695-704. doi:10.1242/jcs.03086

31. Denis MM, Tolley ND, Bunting M, Schwertz H, Jiang H, Lindemann S, et al. Escaping the nuclear confines: signal-dependent pre-mRNA splicing in anucleate platelets. Cell (2005) 122(3):379-91. doi:10.1016/j.cell.2005.06.015

32. McRedmond JP, Park SD, Reilly DF, Coppinger JA, Maguire PB, Shields DC, et al. Integration of proteomics and genomics in platelets: a profile of platelet proteins and platelet-specific genes. Mol Cell Proteomics (2004) 3(2):133-44. doi:10.1074/mcp.M300063-MCP200

33. Garcia-Bates TM, Lehmann GM, Simpson-Haidaris PJ, Bernstein SH, Sime PJ, Phipps RP. Role of peroxisome proliferator-activated receptor gamma and its ligands in the treatment of hematological malignancies. PPAR Res (2008) 2008:834612. doi:10.1155/2008/834612

34. Ray DM, Spinelli SL, Pollock SJ, Murant TI, O’Brien JJ, Blumberg N, et al. Peroxisome proliferator-activated receptor gamma and retinoid $\mathrm{X}$ receptor transcription factors are released from activated human platelets and shed in microparticles. Thromb Haemost (2008) 99(1):86-95. doi:10.1160/TH07-05-0328

35. Ghanim H, Dhindsa S, Aljada A, Chaudhuri A, Viswanathan P, Dandona P. Low-dose rosiglitazone exerts an antiinflammatory effect with an increase in adiponectin independently of free fatty acid fall and insulin sensitization in obese type 2 diabetics. J Clin Endocrinol Metab (2006) 91(9):3553-8. doi:10.1210/jc.2005-2609

36. Randriamboavonjy V, Pistrosch F, Bölck B, Schwinger RH, Dixit M, Badenhoop $\mathrm{K}$, et al. Platelet sarcoplasmic endoplasmic reticulum Ca2+-ATPase and mucalpain activity are altered in type 2 diabetes mellitus and restored by rosiglitazone. Circulation (2008) 117(1):52-60. doi:10.1161/CIRCULATIONAHA.107. 719807 
37. Watala C, Boncler M, Gresner P. Blood platelet abnormalities and pharmacological modulation of platelet reactivity in patients with diabetes mellitus. Pharmacol Rep (2005) 57(Suppl):42-58. doi:10.2174/1381612054367337

38. Gasparyan AY, Ayvazyan L, Mikhailidis DP, Kitas GD. Mean platelet volume: a link between thrombosis and inflammation? Curr Pharm Des (2011) 17(1):47-58. doi:10.2174/138161211795049804

39. Trovati M, Anfossi G. Mechanisms involved in platelet hyperactivation and platelet-endothelium interrelationships in diabetes mellitus. Curr Diab Rep (2002) 2(4):316-22. doi:10.1007/s11892-002-0020-7

40. Hetzel J, Balletshofer B, Rittig K, Walcher D, Kratzer W, Hombach V, et al. Rapid effects of rosiglitazone treatment on endothelial function and inflammatory biomarkers. Arterioscler Thromb Vasc Biol (2005) 25(9):1804-9. doi:10.1161/ 01.ATV.0000176192.16951.9a

41. Pfützner A, Schöndorf T, Seidel D, Winkler K, Matthaei S, Hamann A, et al. Impact of rosiglitazone on beta-cell function, insulin resistance, and adiponectin concentrations: results from a double-blind oral combination study with glimepiride. Metabolism (2006) 55(1):20-5. doi:10.1016/j.metabol. 2005.06.021

42. Derosa G, Cicero AF, Gaddi A, Ragonesi PD, Piccinni MN, Fogari E, et al. A comparison of the effects of pioglitazone and rosiglitazone combined with glimepiride on prothrombotic state in type 2 diabetic patients with the metabolic syndrome. Diabetes Res Clin Pract (2005) 69(1):5-13. doi:10.1016/j. diabres.2004.10.007

43. Fonseca VA, Reynolds T, Hemphill D, Randolph C, Wall J, Valiquet TR, et al. Effect of troglitazone on fibrinolysis and activated coagulation in patients with non-insulin-dependent diabetes mellitus. J Diabetes Complications (1998) 12(4):181-6. doi:10.1016/S1056-8727(97)00109-8

44. Kato K, Yamada D, Midorikawa S, Sato W, Watanabe T. Improvement by the insulin-sensitizing agent, troglitazone, of abnormal fibrinolysis in type 2 diabetes mellitus. Metabolism (2000) 49(5):662-5. doi:10.1016/S0026-0495(00) 80045- 1

45. Sidhu JS, Cowan D, Kaski JC. The effects of rosiglitazone, a peroxisome proliferator-activated receptor-gamma agonist, on markers of endothelial cell activation, C-reactive protein, and fibrinogen levels in non-diabetic coronary artery disease patients. J Am Coll Cardiol (2003) 42(10):1757-63. doi:10.1016/ j.jacc.2003.04.001

46. Haffner SM, Greenberg AS, Weston WM, Chen H, Williams K, Freed MI. Effect of rosiglitazone treatment on nontraditional markers of cardiovascular disease in patients with type 2 diabetes mellitus. Circulation (2002) 106(6):679-84. doi:10.1161/01.CIR.0000025403.20953.23

47. Chu CS, Lee KT, Lee MY, Su HM, Voon WC, Sheu SH, et al. Effects of rosiglitazone alone and in combination with atorvastatin on nontraditional markers of cardiovascular disease in patients with type 2 diabetes mellitus. Am J Cardiol (2006) 97(5):646-50. doi:10.1016/j.amjcard.2005.09.101

48. Yu J, Jin N, Wang G, Zhang F, Mao J, Wang X. Peroxisome proliferatoractivated receptor gamma agonist improves arterial stiffness in patients with type 2 diabetes mellitus and coronary artery disease. Metabolism (2007) 56(10):1396-401. doi:10.1016/j.metabol.2007.05.011

49. Schöndorf T, Musholt PB, Hohberg C, Forst T, Lehmann U, Fuchs W, et al. The fixed combination of pioglitazone and metformin improves biomarkers of platelet function and chronic inflammation in type 2 diabetes patients: results from the PIOfix study. J Diabetes Sci Technol (2011) 5(2):426-32. doi:10.1177/193229681100500233

50. Samaha FF, Szapary PO, Iqbal N, Williams MM, Bloedon LT, Kochar A, et al. Effects of rosiglitazone on lipids, adipokines, and inflammatory markers in nondiabetic patients with low high-density lipoprotein cholesterol and metabolic syndrome. Arterioscler Thromb Vasc Biol (2006) 26(3):624-30. doi:10.1161/01.ATV.0000200136.56716.30

51. Chu JW, Abbasi F, Lamendola C, McLaughlin T, Reaven GM, Tsao PS. Effect of rosiglitazone treatment on circulating vascular and inflammatory markers in insulin-resistant subjects. Diab Vasc Dis Res (2005) 2(1):37-41. doi:10.3132/dvdr.2005.004

52. Marx N, Imhof A, Froehlich J, Siam L, Ittner J, Wierse G, et al. Effect of rosiglitazone treatment on soluble CD40L in patients with type 2 diabetes and coronary artery disease. Circulation (2003) 107(15):1954-7. doi:10.1161/01.CIR. 0000069272.06194 .91

53. Khanolkar MP, Morris RH, Thomas AW, Bolusani H, Roberts AW, Geen J, et al. Rosiglitazone produces a greater reduction in circulating platelet activity compared with gliclazide in patients with type 2 diabetes mellitus - an effect probably mediated by direct platelet PPARgamma activation. Atherosclerosis (2008) 197(2):718-24. doi:10.1016/j.atherosclerosis.2007.07.020

54. Sidhu JS, Cowan D, Tooze JA, Kaski JC. Peroxisome proliferator-activated receptor-gamma agonist rosiglitazone reduces circulating platelet activity in patients without diabetes mellitus who have coronary artery disease. Am Heart $J$ (2004) 147(6):e25. doi:10.1016/j.ahj.2003.12.035

55. Akbiyik F, Ray DM, Gettings KF, Blumberg N, Francis CW, Phipps RP. Human bone marrow megakaryocytes and platelets express PPARgamma, and PPARgamma agonists blunt platelet release of CD40 ligand and thromboxanes. Blood (2004) 104(5):1361-8. doi:10.1182/blood-2004-03-0926

56. Hishinuma T, Yamazaki T, Mizugaki M. Troglitazone has a reducing effect on thromboxane production. Prostaglandins Other Lipid Mediat (2000) 62(2):135-43. doi:10.1016/S0090-6980(00)00059-9

57. Bodary PF, Vargas FB, King SA, Jongeward KL, Wickenheiser KJ, Eitzman DT. Pioglitazone protects against thrombosis in a mouse model of obesity and insulin resistance. J Thromb Haemost (2005) 3(10):2149-53. doi:10.1111/j. 1538-7836.2005.01551.x

58. Rao F, Yang RQ, Chen XS, Xu JS, Fu HM, Su H, et al. PPAR $\gamma$ ligands decrease hydrostatic pressure-induced platelet aggregation and proinflammatory activity. PLoS One (2014) 9(2):e89654. doi:10.1371/journal.pone. 0089654

59. Li D, Chen K, Sinha N, Zhang X, Wang Y, Sinha AK, et al. The effects of PPAR-gamma ligand pioglitazone on platelet aggregation and arterial thrombus formation. Cardiovasc Res (2005) 65(4):907-12. doi:10.1016/j.cardiores. 2004.11.027

60. Varo N, Vicent D, Libby P, Nuzzo R, Calle-Pascual AL, Bernal MR, et al. Elevated plasma levels of the atherogenic mediator soluble CD40 ligand in diabetic patients: a novel target of thiazolidinediones. Circulation (2003) 107(21):2664-9. doi:10.1161/01.CIR.0000074043.46437.44

61. Surh YJ, Na HK, Park JM, Lee HN, Kim W, Yoon IS, et al. 15-Deoxy- $\delta^{12},{ }^{14}$ prostaglandin $\mathrm{J}_{2}$, an electrophilic lipid mediator of anti-inflammatory and proresolving signaling. Biochem Pharmacol (2011) 82(10):1335-51. doi:10.1016/j. bcp.2011.07.100

62. Ishizuka $\mathrm{T}$, Itaya S, Wada $\mathrm{H}$, Ishizawa M, Kimura M, Kajita K, et al. Differential effect of the antidiabetic thiazolidinediones troglitazone and pioglitazone on human platelet aggregation mechanism. Diabetes (1998) 47(9):1494-500. doi:10.2337/diabetes.47.9.1494

63. Smith NJ, Stoddart LA, Devine NM, Jenkins L, Milligan G. The action and mode of binding of thiazolidinedione ligands at free fatty acid receptor 1. J Biol Chem (2009) 284(26):17527-39. doi:10.1074/jbc.M109.012849

64. Simó R, Rodriguez A, Caveda E. Different effects of thiazolidinediones on cardiovascular risk in patients with type 2 diabetes mellitus: pioglitazone versus rosiglitazone. Curr Drug Saf (2010) 5(3):234-44. doi:10.2174/ 157488610791698352

65. Pickavance L, Widdowson PS, King P, Ishii S, Tanaka H, Williams G. The development of overt diabetes in young Zucker diabetic fatty (ZDF) rats and the effects of chronic MCC-555 treatment. Br J Pharmacol (1998) 125(4):767-70. doi:10.1038/sj.bjp.0702158

66. Choi J, Park Y, Lee HS, Yang Y, Yoon S. 1,3-diphenyl-1H-pyrazole derivatives as a new series of potent PPAR $\gamma$ partial agonists. Bioorg Med Chem (2010) 18(23):8315-23. doi:10.1016/j.bmc.2010.09.068

67. Camp HS, Li O, Wise SC, Hong YH, Frankowski CL, Shen X, et al. Differential activation of peroxisome proliferator-activated receptor-gamma by troglitazone and rosiglitazone. Diabetes (2000) 49(4):539-47. doi:10.2337/diabetes. 49.4.539

68. Guan HP, Ishizuka T, Chui PC, Lehrke M, Lazar MA. Corepressors selectively control the transcriptional activity of PPARgamma in adipocytes. Genes Dev (2005) 19(4):453-61. doi:10.1101/gad.1263305

69. Kodera Y, Takeyama K, Murayama A, Suzawa M, Masuhiro Y, Kato S. Ligand type-specific interactions of peroxisome proliferator-activated receptor gamma with transcriptional coactivators. J Biol Chem (2000) 275(43):33201-4. doi:10.1074/jbc.C000517200

70. Lonard DM, O'Malley BW. Nuclear receptor coregulators: modulators of pathology and therapeutic targets. Nat Rev Endocrinol (2012) 8(10):598-604. doi:10.1038/nrendo.2012.100

71. Moraes LA, Spyridon M, Kaiser WJ, Jones CI, Sage T, Atherton RE, et al. Nongenomic effects of PPARgamma ligands: inhibition of GPVI-stimulated platelet activation. J Thromb Haemost (2010) 8(3):577-87. doi:10.1111/j.1538-7836. 2009.03732.x 
72. Sahler J, Woeller C, Spinelli S, Blumberg N, Phipps R. A novel method for overexpression of peroxisome proliferator-activated receptor- $\gamma$ in megakaryocyte and platelet microparticles achieves transcellular signaling. J Thromb Haemost (2012) 10(12):2563-72. doi:10.1111/jth.12017

73. Du H, Hu H, Zheng H, Hao J, Yang J, Cui W. Effects of peroxisome proliferatoractivated receptor $\gamma$ in simvastatin antiplatelet activity: influences on cAMP and mitogen-activated protein kinases. Thromb Res (2014) 134(1):111-20. doi:10.1016/j.thromres.2014.05.005

74. Ali FY, Armstrong PC, Dhanji AR, Tucker AT, Paul-Clark MJ, Mitchell JA, et al. Antiplatelet actions of statins and fibrates are mediated by PPARs. Arterioscler Thromb Vasc Biol (2009) 29(5):706-11. doi:10.1161/ATVBAHA.108. 183160

75. Kliewer SA, Forman BM, Blumberg B, Ong ES, Borgmeyer U, Mangelsdorf DJ, et al. Differential expression and activation of a family of murine peroxisome proliferator-activated receptors. Proc Natl Acad Sci US A (1994) 91(15):7355-9. doi:10.1073/pnas.91.15.7355

76. Ali FY, Davidson SJ, Moraes LA, Traves SL, Paul-Clark M, Bishop-Bailey D, et al. Role of nuclear receptor signaling in platelets: antithrombotic effects of PPARbeta. FASEB J (2006) 20(2):326-8. doi:10.1096/fj.05-4395fje

77. Ali FY, Hall MG, Desvergne B, Warner TD, Mitchell JA. PPARbeta/delta agonists modulate platelet function via a mechanism involving PPAR receptors and specific association/repression of PKCalpha - brief report. Arterioscler Thromb Vasc Biol (2009) 29(11):1871-3. doi:10.1161/ATVBAHA.109. 193367

78. Lim H, Dey SK. PPAR delta functions as a prostacyclin receptor in blastocyst implantation. Trends Endocrinol Metab (2000) 11(4):137-42. doi:10.1016/ S1043-2760(00)00243-5

79. Fuentes E, Palomo I. Mechanism of antiplatelet action of hypolipidemic, antidiabetic and antihypertensive drugs by PPAR activation: PPAR agonists: new antiplatelet agents. Vascul Pharmacol (2014) 62(3):162-6. doi:10.1016/j.vph. 2014.05.008

80. Chou TC, Shih CY, Chen YT. Inhibitory effect of $\alpha$-lipoic acid on platelet aggregation is mediated by PPARs. J Agric Food Chem (2011) 59(7):3050-9. doi:10.1021/jf103940u

81. Feinstein DL, Spagnolo A, Akar C, Weinberg G, Murphy P, Gavrilyuk V, et al. Receptor-independent actions of PPAR thiazolidinedione agonists: is mitochondrial function the key? Biochem Pharmacol (2005) 70(2):177-88. doi:10.1016/j.bcp.2005.03.033

82. Luconi M, Cantini G, Serio M. Peroxisome proliferator-activated receptor gamma (PPARgamma): is the genomic activity the only answer? Steroids (2010) 75(8-9):585-94. doi:10.1016/j.steroids.2009.10.012

83. Robinson E, Grieve DJ. Significance of peroxisome proliferator-activated receptors in the cardiovascular system in health and disease. Pharmacol Ther (2009) 122(3):246-63. doi:10.1016/j.pharmthera.2009.03.003

84. Kelly D, Campbell JI, King TP, Grant G, Jansson EA, Coutts AG, et al. Commensal anaerobic gut bacteria attenuate inflammation by regulating nuclear-cytoplasmic shuttling of PPAR-gamma and RelA. Nat Immunol (2004) 5(1):104-12. doi:10.1038/ni1018

85. von Knethen A, Soller M, Tzieply N, Weigert A, Johann AM, Jennewein C, et al. PPARgammal attenuates cytosol to membrane translocation of PKCalpha to desensitize monocytes/macrophages. J Cell Biol (2007) 176(5):681-94. doi:10.1083/jcb.200605038

86. Paumelle R, Blanquart C, Briand O, Barbier O, Duhem C, Woerly G, et al. Acute antiinflammatory properties of statins involve peroxisome proliferator-activated receptor-alpha via inhibition of the protein kinase $\mathrm{C}$ signaling pathway. Circ Res (2006) 98(3):361-9. doi:10.1161/01.RES.0000202706. 70992.95

87. Jones DC, Ding X, Zhang TY, Daynes RA. Peroxisome proliferator-activated receptor alpha negatively regulates T-bet transcription through suppression of p38 mitogen-activated protein kinase activation. J Immunol (2003) 171(1):196-203. doi:10.4049/jimmunol.171.1.196

88. Saklatvala J, Rawlinson L, Waller RJ, Sarsfield S, Lee JC, Morton LF, et al. Role for p38 mitogen-activated protein kinase in platelet aggregation caused by collagen or a thromboxane analogue. J Biol Chem (1996) 271(12):6586-9. doi:10.1074/jbc.271.12.6586

89. Li Z, Xi X, Du X. A mitogen-activated protein kinase-dependent signaling pathway in the activation of platelet integrin alpha IIbbeta3. J Biol Chem (2001) 276(45):42226-32. doi:10.1074/jbc.M106129200
90. Li Z, Zhang G, Feil R, Han J, Du X. Sequential activation of p38 and ERK pathways by cGMP-dependent protein kinase leading to activation of the platelet integrin alphaIIb beta3. Blood (2006) 107(3):965-72. doi:10.1182/blood-200503-1308

91. Burgermeister E, Seger R. PPARgamma and MEK interactions in cancer. PPAR Res (2008) 2008:309469. doi:10.1155/2008/309469

92. Cantini G, Lombardi A, Borgogni E, Francalanci M, Ceni E, Degl'Innocenti $\mathrm{S}$, et al. Peroxisome-proliferator-activated receptor gamma (PPARgamma) is required for modulating endothelial inflammatory response through a nongenomic mechanism. Eur J Cell Biol (2010) 89(9):645-53. doi:10.1016/j.ejcb. 2010.04.002

93. Cantini G, Lombardi A, Piscitelli E, Poli G, Ceni E, Marchiani S, et al. Rosiglitazone inhibits adrenocortical cancer cell proliferation by interfering with the IGF-IR intracellular signaling. PPAR Res (2008) 2008:904041. doi:10.1155/2008/904041

94. Papageorgiou E, Pitulis N, Manoussakis M, Lembessis P, Koutsilieris M. Rosiglitazone attenuates insulin-like growth factor 1 receptor survival signaling in PC-3 cells. Mol Med (2008) 14(7-8):403-11. doi:10.2119/2008-00021. Papageorgiou

95. Ichiki T, Tokunou T, Fukuyama K, Iino N, Masuda S, Takeshita A. 15deoxy-delta12,14-prostaglandin $\mathrm{J} 2$ and thiazolidinediones transactivate epidermal growth factor and platelet-derived growth factor receptors in vascular smooth muscle cells. Biochem Biophys Res Commun (2004) 323(2):402-8. doi:10.1016/j.bbrc.2004.08.101

96. Endo Y, Suzuki M, Yamada H, Horita S, Kunimi M, Yamazaki O, et al. Thiazolidinediones enhance sodium-coupled bicarbonate absorption from renal proximal tubules via PPAR $\gamma$-dependent nongenomic signaling. Cell Metab (2011) 13(5):550-61. doi:10.1016/j.cmet.2011.02.015

97. Lehmann JM, Kliewer SA, Moore LB, Smith-Oliver TA, Oliver BB, Su JL, et al. Activation of the nuclear receptor LXR by oxysterols defines a new hormone response pathway. J Biol Chem (1997) 272(6):3137-40. doi:10.1074/jbc. 272.6.3137

98. Peet DJ, Turley SD, Ma W, Janowski BA, Lobaccaro JM, Hammer RE, et al. Cholesterol and bile acid metabolism are impaired in mice lacking the nuclear oxysterol receptor LXR alpha. Cell (1998) 93(5):693-704. doi:10.1016/S00928674(00)81432-4

99. Spyridon M, Moraes LA, Jones CI, Sage T, Sasikumar P, Bucci G, et al. LXR as a novel antithrombotic target. Blood (2011) 117(21):5751-61. doi:10.1182/ blood-2010-09-306142

100. Yue L, Ye F, Gui C, Luo H, Cai J, Shen J, et al. Ligand-binding regulation of LXR/RXR and LXR/PPAR heterodimerizations: SPR technology-based kinetic analysis correlated with molecular dynamics simulation. Protein Sci (2005) 14(3):812-22. doi:10.1110/ps.04951405

101. Mangelsdorf DJ, Ong ES, Dyck JA, Evans RM. Nuclear receptor that identifies a novel retinoic acid response pathway. Nature (1990) 345(6272):224-9. doi: $10.1038 / 345224 \mathrm{a} 0$

102. Chambon P. A decade of molecular biology of retinoic acid receptors. FASEB J (1996) 10(9):940-54.

103. Moraes LA, Swales KE, Wray JA, Damazo A, Gibbins JM, Warner TD, et al. Nongenomic signaling of the retinoid $\mathrm{X}$ receptor through binding and inhibiting Gq in human platelets. Blood (2007) 109(9):3741-4. doi:10.1182/blood2006-05-022566

104. Schaaf MJ, Cidlowski JA. Molecular mechanisms of glucocorticoid action and resistance. J Steroid Biochem Mol Biol (2002) 83(1-5):37-48. doi:10.1016/ S0960-0760(02)00263-7

105. Sanner BM, Meder U, Zidek W, Tepel M. Effects of glucocorticoids on generation of reactive oxygen species in platelets. Steroids (2002) 67(8):715-9. doi:10.1016/S0039-128X(02)00024-7

106. Moraes LA, Paul-Clark MJ, Rickman A, Flower RJ, Goulding NJ, Perretti M. Ligand-specific glucocorticoid receptor activation in human platelets. Blood (2005) 106(13):4167-75. doi:10.1182/blood-2005-04-1723

107. Hutchison KA, Czar MJ, Pratt WB. Evidence that the hormone-binding domain of the mouse glucocorticoid receptor directly represses DNA binding activity in a major portion of receptors that are "misfolded" after removal of hsp 90 . J Biol Chem (1992) 267(5):3190-5.

108. Jaffe IZ, Tintut Y, Newfell BG, Demer LL, Mendelsohn ME. Mineralocorticoid receptor activation promotes vascular cell calcification. Arterioscler Thromb Vasc Biol (2007) 27(4):799-805. doi:10.1161/01.ATV.0000258414.59393.89 
109. Lindsey S, Papoutsakis ET. The evolving role of the aryl hydrocarbon receptor (AHR) in the normophysiology of hematopoiesis. Stem Cell Rev (2012) 8(4):1223-35. doi:10.1007/s12015-012-9384-5

110. Lindsey S, Jiang J, Woulfe D, Papoutsakis ET. Platelets from mice lacking the aryl hydrocarbon receptor exhibit defective collagen-dependent signaling. JThromb Haemost (2014) 12(3):383-94. doi:10.1111/jth.12490

111. Pearce AC, Senis YA, Billadeau DD, Turner M, Watson SP, Vigorito E. Vav1 and vav3 have critical but redundant roles in mediating platelet activation by collagen. J Biol Chem (2004) 279(52):53955-62. doi:10.1074/jbc. M410355200

112. Raulf M, König W. In vitro effects of polychlorinated biphenyls on human platelets. Immunology (1991) 72(2):287-91.

113. Kim S, Sundaramoorthi H, Jagadeeswaran P. Dioxin-induced thrombocyte aggregation in zebrafish. Blood Cells Mol Dis (2014) 54(1):116-22. doi:10.1016/ j.bcmd.2014.07.010

114. Kim DW, Gazourian L, Quadri SA, Romieu-Mourez R, Sherr DH, Sonenshein GE. The RelA NF-kappa B subunit and the aryl hydrocarbon receptor (AhR) cooperate to transactivate the c-myc promoter in mammary cells. Oncogene (2000) 19(48):5498-506. doi:10.1038/sj.onc.1203945

115. Thatcher TH, Maggirwar SB, Baglole CJ, Lakatos HF, Gasiewicz TA, Phipps RP, et al. Aryl hydrocarbon receptor-deficient mice develop heightened inflammatory responses to cigarette smoke and endotoxin associated with rapid loss of the nuclear factor-kappaB component RelB. Am J Pathol (2007) 170(3):855-64. doi:10.2353/ajpath.2007.060391

116. Baglole CJ, Maggirwar SB, Gasiewicz TA, Thatcher TH, Phipps RP, Sime PJ. The aryl hydrocarbon receptor attenuates tobacco smoke-induced cyclooxygenase2 and prostaglandin production in lung fibroblasts through regulation of the NF-kappa B family member RelB. J Biol Chem (2008) 283(43):28944-57. doi:10.1074/jbc.M800685200

117. Marienfeld R, Berberich-Siebelt F, Berberich I, Denk A, Serfling E, Neumann M. Signal-specific and phosphorylation-dependent RelB degradation: a potential mechanism of NF-kappa B control. Oncogene (2001) 20(56):8142-7. doi:10.1038/sj.onc.1204884

118. Ezumi Y, Takayama H, Okuma M. Thrombopoietin, c-Mpl ligand, induces tyrosine phosphorylation of Tyk2, JAK2, and STAT3, and enhances agonistsinduced aggregation in platelets in vitro. FEBS Lett (1995) 374(1):48-52. doi:10.1016/0014-5793(95)01072-M

119. Miyakawa Y, Oda A, Druker BJ, Ozaki K, Handa M, Ohashi H, et al. Thrombopoietin and thrombin induce tyrosine phosphorylation of Vav in human blood platelets. Blood (1997) 89(8):2789-98.

120. Zhou Z, Gushiken FC, Bolgiano D, Salsbery BJ, Aghakasiri N, Jing N, et al. Signal transducer and activator of transcription 3 (STAT3) regulates collageninduced platelet aggregation independently of its transcription factor activity. Circulation (2013) 127(4):476-85. doi:10.1161/CIRCULATIONAHA.112. 132126

121. Lu WJ, Lin KC, Huang SY, Thomas PA, Wu YH, Wu HC, et al. Role of a Janus kinase 2-dependent signaling pathway in platelet activation. Thromb Res (2014) 133(6):1088-96. doi:10.1016/j.thromres.2014.03.042

122. Ratajczak J, Wysoczynski M, Hayek F, Janowska-Wieczorek A, Ratajczak MZ. Membrane-derived microvesicles: important and underappreciated mediators of cell-to-cell communication. Leukemia (2006) 20(9):1487-95. doi:10.1038/ sj.leu.2404296

123. Del Conde I, Shrimpton CN, Thiagarajan P, López JA. Tissue-factorbearing microvesicles arise from lipid rafts and fuse with activated platelets to initiate coagulation. Blood (2005) 106(5):1604-11. doi:10.1182/blood-200403- 1095

124. Horstman LL, Ahn YS. Platelet microparticles: a wide-angle perspective. Crit Rev Oncol Hematol (1999) 30(2):111-42. doi:10.1016/S1040-8428(98)00044-4

125. Dachary-Prigent J, Freyssinet JM, Pasquet JM, Carron JC, Nurden AT. Annexin $\mathrm{V}$ as a probe of aminophospholipid exposure and platelet membrane vesiculation: a flow cytometry study showing a role for free sulfhydryl groups. Blood (1993) 81(10):2554-65.
126. Dean WL, Lee MJ, Cummins TD, Schultz DJ, Powell DW. Proteomic and functional characterisation of platelet microparticle size classes. Thromb Haemost (2009) 102(4):711-8. doi:10.1160/TH09-04-243

127. Bastos-Amador P, Royo F, Gonzalez E, Conde-Vancells J, Palomo-Diez L, Borras FE, et al. Proteomic analysis of microvesicles from plasma of healthy donors reveals high individual variability. J Proteomics (2012) 75(12):3574-84. doi:10.1016/j.jprot.2012.03.054

128. Burger D, Schock S, Thompson CS, Montezano AC, Hakim AM, Touyz RM. Microparticles: biomarkers and beyond. Clin Sci (Lond) (2013) 124(7):423-41. doi:10.1042/CS20120309

129. Camussi G, Deregibus MC, Bruno S, Cantaluppi V, Biancone L. Exosomes/microvesicles as a mechanism of cell-to-cell communication. Kidney Int (2010) 78(9):838-48. doi:10.1038/ki.2010.278

130. Rozmyslowicz T, Majka M, Kijowski J, Murphy SL, Conover DO, Poncz M, et al. Platelet- and megakaryocyte-derived microparticles transfer CXCR4 receptor to CXCR4-null cells and make them susceptible to infection by X4-HIV. AIDS (2003) 17(1):33-42. doi:10.1097/00002030-200301030-00006

131. Barry OP, Pratico D, Lawson JA, FitzGerald GA. Transcellular activation of platelets and endothelial cells by bioactive lipids in platelet microparticles. J Clin Invest (1997) 99(9):2118-27. doi:10.1172/JCI119385

132. Mause SF, Weber C. Microparticles: protagonists of a novel communication network for intercellular information exchange. Circ Res (2010) 107(9):1047-57. doi:10.1161/CIRCRESAHA.110.226456

133. Garcia BA, Smalley DM, Cho H, Shabanowitz J, Ley K, Hunt DF. The platelet microparticle proteome. J Proteome Res (2005) 4(5):1516-21. doi:10.1021/ pr0500760

134. Feldon SE, O'loughlin CW, Ray DM, Landskroner-Eiger S, Seweryniak KE Phipps RP. Activated human T lymphocytes express cyclooxygenase- 2 and produce proadipogenic prostaglandins that drive human orbital fibroblast differentiation to adipocytes. Am J Pathol (2006) 169(4):1183-93. doi:10.2353/ ajpath.2006.060434

135. Sahler J, Woeller CF, Phipps RP. Microparticles engineered to highly express peroxisome proliferator-activated receptor- $\gamma$ decreased inflammatory mediator production and increased adhesion of recipient monocytes. PLoS One (2014) 9(11):e113189. doi:10.1371/journal.pone.0113189

136. Liu H, Shi B, Huang CC, Eksarko P, Pope RM. Transcriptional diversity during monocyte to macrophage differentiation. Immunol Lett (2008) 117(1):70-80. doi:10.1016/j.imlet.2007.12.012

137. Tontonoz P, Nagy L, Alvarez JG, Thomazy VA, Evans RM. PPARgamma promotes monocyte/macrophage differentiation and uptake of oxidized LDL. Cell (1998) 93(2):241-52. doi:10.1016/S0092-8674(00)81575-5

Conflict of Interest Statement: Neil Blumberg has received lecture honoraria and consulting fees from Antek, Inc., Fenwal, Pall BioMedical, and Caridian (Terumo), manufacturers of leukoreduction filters, blood component equipment, and cell washing devices. The other authors have nothing to disclose.

Received: 09 December 2014; paper pending published: 06 January 2015; accepted: 26 January 2015; published online: 13 February 2015.

Citation: Lannan KL, Sahler J, Kim N, Spinelli SL, Maggirwar SB, Garraud O, Cognasse F, Blumberg $N$ and Phipps RP (2015) Breaking the mold: transcription factors in the anucleate platelet and platelet-derived microparticles. Front. Immunol. 6:48. doi: 10.3389/fimmu.2015.00048

This article was submitted to Inflammation, a section of the journal Frontiers in Immunology.

Copyright (c) 2015 Lannan, Sahler, Kim, Spinelli, Maggirwar, Garraud, Cognasse, Blumberg and Phipps. This is an open-access article distributed under the terms of the Creative Commons Attribution License (CC BY). The use, distribution or reproduction in other forums is permitted, provided the original author(s) or licensor are credited and that the original publication in this journal is cited, in accordance with accepted academic practice. No use, distribution or reproduction is permitted which does not comply with these terms. 